\title{
Ionic Liquids Made with Dimethyl Carbonate: Solvents as well as Boosted Basic Catalysts for the Michael Reaction
}

\author{
Massimo Fabris, Vittorio Lucchini, Marco Noè, Alvise Perosa,* and Maurizio Selva ${ }^{[a]}$
}

\begin{abstract}
This article describes 1) a methodology for the green synthesis of a class of methylammonium and methylphosphonium ionic liquids (ILs), 2) how to tune their acid-base properties by anion exchange, 3) complete neat-phase NMR spectroscopic characterisation of these materials and 4) their application as active organocatalysts for base-promoted carboncarbon bond-forming reactions. Methylation of tertiary amines or phosphines with dimethyl carbonate leads to the formation of the halogen-free methyl-onium methyl carbonate salts, and these can be easily anion-exchanged to yield a range of derivatives
\end{abstract}

with different melting points, solubility, acid-base properties, stability and viscosity. Treatment with water, in particular, yields bicarbonate-exchanged liquid onium salts. These proved strongly basic, enough to efficiently catalyse the Michael reaction; experiments suggest that in these systems the bicarbonate basicity is boosted by two orders of magnitude with respect to inorganic bicarbonate salts. These basic ionic liquids used in catalytic amounts

Keywords: dimethyl carbonate green chemistry $\cdot$ ionic liquids $\cdot$ Michael addition $\cdot$ NMR spectroscopy are better even than traditional strong organic bases. The present work also introduces neat NMR spectroscopy of the ionic liquids as a probe for solutesolvent interactions as well as a tool for characterisation. Our studies show that high catalytic efficacy of functional ionic liquids can be achieved by integrating their green synthesis, along with a fine-tuning of their structure. Demonstrating that ionic liquid solvents can be made by a truly green procedure, and that their properties and reactivity can be tailored to the point of bridging the gap between their use as solvents and as catalysts.

\section{Introduction}

We cannot emphasise too much that ionic liquids (ILs) have elicited phenomenal interest, in particular among chemists who develop novel systems for clean catalysis ${ }^{[1]}$ and also in the chemical industry. ${ }^{[2]}$ A degree of controversy still exists concerning their absolute greenness, partly because the toxicity and biodegradability of ionic liquids need to be fully assessed, but also partly because the prediction of their properties by comparison with a structurally similar one can be difficult for a number of reasons: 1) the number of cationanion pairs is limitless, 2) each ion exhibits its own proper-

[a] Dr. M. Fabris, Prof. V. Lucchini, Dr. M. Noè, Dr. A. Perosa, Prof. M. Selva

Università Ca' Foscari, Dipartimento di Scienze Ambientali Dorsoduro, 2137-30123 Venezia (Italy)

Fax: (+39)041-234-8584

E-mail: alvise@unive.it

Supporting Information for this article (IR, ${ }^{1} \mathrm{H}$ and ${ }^{13} \mathrm{C}\left\{{ }^{1} \mathrm{H}\right\}$ NMR spectra of all compounds) is available on the WWW under http://dx.doi.org/10.1002/chem.200901891. ties, 3) each pair may behave differently, even just with respect to the sum of its components and 4) any forecasted characteristic always requires empirical confirmation. Therefore, the prediction of physical, chemical, toxicological and biological features of ionic liquids should be based on quantitative methods able to correlate their structure to the property of interests rather than on an "intuitive similarity" that can be misleading and often wrong. ${ }^{[3]}$ Examples of such a quantitative structure-property relationship approach were recently described and used, for example, to correlate ionic liquid descriptors with their melting points ${ }^{[4]}$ and with the partition ratios of dibenzothiophene in different ionic liquids. ${ }^{[5]}$ Notwithstanding the complexity of the issue, it is accepted that in many instances ionic liquids are a viable green alternative to conventional molecular solvents. And that it is possible to design, optimise and apply the right ionic liquid for one's specific case. Phosphonium-based ionic liquids, which have been known and used for a long time as phase-transfer catalysts, ${ }^{[6]}$ are particularly appealing ${ }^{[7]}$ on account of their ease of preparation with high purity, their transparency and their higher stability toward thermal and chemical degradation compared with the homologous am- 
monium salts. They are therefore finding increased use in chemical applications. ${ }^{[8,9]}$

A limitation of ionic liquids lies in their manufacturing process, which is frequently not green. Their synthesis, in fact, involves two potentially environmentally adverse steps: quaternarisation of a nitrogen or phosphorous atom, usually by methylation with hazardous alkyl halides (e.g., $\mathrm{CH}_{3} \mathrm{Cl}$; Scheme 1), followed by a halogen anion metathesis step that

$$
\begin{aligned}
\mathrm{R}_{3} \mathrm{~N}+\mathrm{CH}_{3} \mathrm{X} \longrightarrow & \mathrm{R}_{3} \stackrel{\oplus}{\mathrm{N}} \mathrm{CH}_{3} \stackrel{\ominus}{\mathrm{X}} \stackrel{\mathrm{NaY}}{\longrightarrow} \mathrm{R}_{3} \stackrel{\oplus}{\mathrm{N}} \mathrm{CH}_{3} \stackrel{\ominus}{\mathrm{Y}}+\mathrm{NaX} \\
& \mathrm{X}=\text { halide, } \mathrm{OSO}_{3} \mathrm{CH}_{3}
\end{aligned}
$$

Scheme 1 . Tertiary amine methylation with $\mathrm{CH}_{3} \mathrm{X}$ and halide anion exchange

produces equimolar amounts of an inorganic salt. ${ }^{[3,10]}$ In addition, the materials thus prepared inevitably contain residual undesirable halide ions. Although these steps can be optimised in a number of ways, for example, by halide-free syntheses, ${ }^{[11-13]}$ they still often use hazardous and highly toxic reagents such as methyl halides and dimethylsulfate (DMS) ${ }^{[14]}$ and generate unwanted byproducts.

Quaternarisation of nitrogen (or phosphorous) generates the ionic onium $\left(\mathrm{Q}^{+}\right)$species, and depending on the methylating agent used, this step ends up incorporating the counteranion in the IL. Therefore the choice of an alkylating agent different from alkyl halides can circumvent inclusion of halogens in the ionic liquids, and it can also provide safer alternatives to the use of DMS and $\mathrm{CH}_{3} \mathrm{X}$.

Proionic (Production of Ionic Substances, $\mathrm{GmbH}$ ), for example, has patented and commercialised a method for the quaternarisation of amines, phosphines, sulfides and imidazoles using dialkyl carbonates that yields an alkyl carbonate or hydrogen carbonate anion. ${ }^{[15]}$ The second steps involve metathesis of the anion with a Brønsted acid. These ionic liquids are commercialised as water-methanol solutions with the trademark CBILS. ${ }^{[16]}$ However, the patent is cryptic on the synthetic conditions, the characterisation, the stability and their storage. Another report describes the electrochemical synthesis of tetramethylammonium hydroxide initiated by methylation of trimethylamine with dimethyl carbonate (DMC) ${ }^{[17]}$ Among the proposed intermediates there is tetramethylammonium hydrogen carbonate; however, this study also lacks characterisation on these species.

Our longstanding interest in the use of dialkyl carbonates as green alkylating agents, particularly of DMC ${ }^{[18,19]}$ was applied to the synthesis of task-specific and very pure ionic liquids by means of methylation of phosphines and amines.

The initial focus was on Aliquat336 (A336), tricaprylylmethylammonium chloride, a largely available ammonium phase-transfer catalyst, which is, despite its commercial distribution, highly impure due to the presence of both $\mathrm{C}_{10}$ and $\mathrm{C}_{8}$ alkyl chains, as well as of decanol and octanol. We were able to prepare pure trioctlymethylammonium chloride by adapting a synthesis reported by Noyori et al. using DMS, ${ }^{[20]}$ followed by anion exchange to yield the chloride (Scheme 1). This synthesis suffered from a number of drawbacks including long reaction times, use of toxic DMS and the formation of a coloured ionic liquid. ${ }^{[21]}$ Our initial aim was therefore to develop an alternative synthetic procedure of these ionic liquids by using DMC as the green methyl source, and to prepare pure products in relatively large batches (20-40 g).

Here we describe a route based on the use of DMC for the synthesis for a series of new ionic liquids, in view of applications in multiphase catalysis, ${ }^{[22]}$ nanoparticle formation, ${ }^{[23]}$ and IL-mediated organic synthesis. Some of these ionic liquids showed peculiar and very remarkable built-in basicity and were investigated as catalysts for the formation of carbonucleophiles. In particular, this work discusses the synthesis of a series of methylammonium- and methylphosphonium-based ionic liquids by means of methylation of the parent amines with DMC. Depending on the nature of the anion, these ionic materials are also highly active as basic catalysts for carbon-carbon bond-forming Michael reactions. The study is divided into four sections that represent an integrated ionic-liquid synthesis-application methodology: 1) the halide-free preparation of a series of pure methylonium (ammonium and phosphonium) ionic liquids through the use of DMC as quaternarisation agent; 2) a simple procedure for anion metathesis with Brønsted acids or water as new anion source, and no use of solvents; 3 ) the complete NMR spectroscopic characterisation of the ionic liquids in the neat phase; 4) a demonstration that some members of this category of ionic liquids are functional catalysts as well as solvents, that is, they possess an unexpected basicity that make them excellent organocatalysts for $\mathrm{C}-\mathrm{C}$ bond-forming reactions, even when used only $0.4 \%$ molar with respect to the substrate.

\section{Results}

Quaternarisation with DMC: The synthesis of the ionic liquids involved the reaction of DMC with trioctylamine (TOA) and trioctylphosphine (TOP), to yield the corresponding methyl-onium methyl carbonate salts $\mathbf{1}$ and $\mathbf{2}$ [Eqs. (1) and (2), respectively].

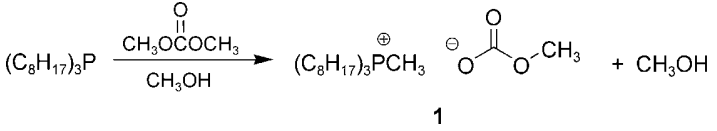

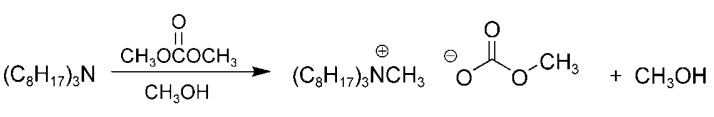

All quaternarisation reactions were run in a sealed steel autoclave as the reaction temperature $\left(>120^{\circ} \mathrm{C}\right)$ was higher than the boiling point of $\mathrm{DMC}\left(90^{\circ} \mathrm{C}\right)$. The operative condi- 
tions for the methylation of TOA and TOP with DMC were determined experimentally, starting from our previous knowledge of the methylating activity of $\mathrm{DMC},{ }^{[24]}$ by testing different amine (and phosphine)/DMC molar ratios and different reaction temperatures with or without the addition of added solvents. Attempts to carry out the reaction in the absence of added solvents, that is, simply by heating a mixture of TOA and a 5-fold molar excess of DMC, proved impractical and yielded unidentified side products, probably due to the immiscibility of the reagents. However, by adding equal volumes of methanol and DMC, the reaction of TOA went to completion at $140^{\circ} \mathrm{C}$ in $20 \mathrm{~h}$ under an $\mathrm{N}_{2}$ atmosphere [Eq. (1)]. The starting mixture was biphasic in the presence $\mathrm{MeOH}$ as well due to the high lipophilicity of trioctylamine, but it is likely that under the reaction conditions a sufficient ratio of amine could come into contact with DMC and drive the reaction forward. In addition, the buildup of the onium ionic liquid may have had a promoting effect on the methylation reaction, as demonstrated in a similar case. ${ }^{[25]}$

From the resulting clear solution, the methanol and DMC were easily removed under vacuum $\left(10^{-2} \mathrm{~atm}, 25^{\circ} \mathrm{C}\right)$ to quantitatively yield the pure methylammonium methyl carbonate salt [TOMA] [CH $\mathrm{CH}_{3} \mathrm{OCOO}$ (2). At this stage, NMR spectroscopic analysis showed the formation of pure ionic liquid that incorporated up to a mole of methanol. This could be removed only by prolonged heating and under high vacuum $\left(10^{-3} \mathrm{~atm}, 40^{\circ} \mathrm{C}\right)$, which, however, caused a slow darkening of the liquid. On the other hand, since the presence of methanol did not interfere with successive transformations, it was deemed inconsequential and thereafter disregarded. An identical procedure was used for the synthesis of the phosphine equivalent [TOMP] $\left[\mathrm{CH}_{3} \mathrm{OCOO}\right](\mathbf{1})$ from TOP and DMC [Eq. (2)]. In this case, a necessary precaution involved eliminating oxygen completely by degassing the reagent mixture by careful freeze-pump-thaw cycles to avoid formation of the phosphine oxide. The product was perfectly clear and colourless and stable in air up to over $150^{\circ} \mathrm{C}$. Both these syntheses could be carried out on $20-30 \mathrm{~g}$ batches of TOA and TOP, thus yielding quantitatively the desired pure product and the volatile byproducts methanol and carbon dioxide. The products $\mathbf{1}$ and $\mathbf{2}$ were clear, colourless to pale yellow liquids, stable in air and could be stored for prolonged periods of time. The phosphonium salt $\mathbf{1}$ was perfectly colourless and more stable toward chemical and thermal degradation with respect to the ammonium analogue.

Anion metathesis: The onium $\left(\mathrm{Q}^{+}\right)$methyl carbonate ionic liquids $\mathbf{1}$ and $\mathbf{2}$ described above reacted readily with Brønsted acids (H-A, Scheme 2) to yield the anion $\left(\mathrm{A}^{-}\right)$-exchanged salt along with methyl hydrogen carbonate (i.e., the half-ester of carbonic acid). The latter was unstable above $-36^{\circ} \mathrm{C}^{[26]}$ and immediately decomposed to form methanol and $\mathrm{CO}_{2}$, thus providing its built-in removal. This exchange procedure was tested for a number of acids, and it involved mixing the precursor ionic liquid with the acid under air, then gently heating $\left(50^{\circ} \mathrm{C}\right)$ and finally removing methanol

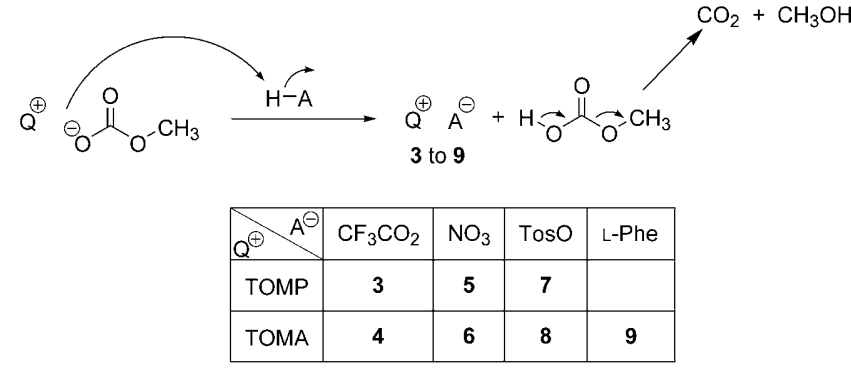

Scheme 2. Reaction products of onium methyl carbonates with Brønsted acids.

and $\mathrm{CO}_{2}$ under vacuum to yield the pure products. It proved simple, rapid, clean and free of any work-up steps.

The outcome was different using water instead of HA. Water promoted transformation of the methyl carbonate anion into the hydrogen carbonate anion to yield [TOMP][HOCOO] (10) and [TOMA][HOCOO] (11) [Eq. (3)]. ${ }^{[17]}$ Both the resulting $\mathbf{1 0}$ and $\mathbf{1 1}$ were deliquescent white solids at room temperature.

$$
Q^{\oplus} \Theta_{\mathrm{O}} \stackrel{\mathrm{O}}{\mathrm{O}^{-} \mathrm{CH}_{3}}+\mathrm{H}_{2} \mathrm{O} \longrightarrow \underset{10,11}{\Theta_{\mathrm{O}}} \stackrel{\mathrm{O}}{\mathrm{OH}}+\mathrm{CH}_{3} \mathrm{OH}
$$

The syntheses of [TOMP][NTf $\left.\mathrm{NT}_{2}\right]\left(\mathbf{1 2} ; \mathrm{NTf}_{2}=\right.$ bis(trifluoromethane)sulfonimide) and [TOMA] $\left[\mathrm{NTf}_{2}\right](\mathbf{1 3})$ represented the only exceptions to the above anion-exchange procedures. Thanks to the lypophilic character of the $\mathrm{NTF}_{2}$ anion, the desired ionic liquids could be precipitated out of an aqueous solution of $\mathbf{1}$ and $\mathbf{2}$ simply by the addition of $\operatorname{LiNTf}_{2}$.

Table 1 shows a summary of the compounds discussed in this study. It should be noted that the tosylate salts $\mathbf{7}$ and $\mathbf{8}$ are listed only in the table. They are not quoted elsewhere due to their excessively high melting point, which inhibited the acquisition of neat NMR spectra at the operating tem-

Table 1. List of ionic liquids described in this study.

\begin{tabular}{lllll}
\hline Compound & $\mathrm{Q}^{+}$ & $\mathrm{A}^{-}$ & $\left.\mathrm{M} \cdot \mathrm{p} .{ }^{\circ} \mathrm{C}\right]$ & Anion precursor \\
\hline $\mathbf{1}$ & TOMP & $\mathrm{CH}_{3} \mathrm{OCOO}$ & $<0^{[\mathrm{a}]}$ & - \\
$\mathbf{2}$ & TOMA & & $<0^{[\mathrm{a}]}$ & \\
$\mathbf{3}$ & TOMP & $\mathrm{CF}_{3} \mathrm{COO}$ & $23-24$ & $\mathrm{CF}_{3} \mathrm{COOH}$ \\
$\mathbf{4}$ & TOMA & & $\mathrm{nd}^{[\mathrm{b}]}$ & \\
$\mathbf{5}$ & TOMP & $\mathrm{NO}_{3}$ & $<0^{[\mathrm{a}]}$ & $\mathrm{HNO}_{3}$ \\
$\mathbf{6}$ & TOMA & & $<0^{[\mathrm{a}]}$ & \\
$\mathbf{7}$ & TOMP & TosO & $96-98$ & TosOH \\
$\mathbf{8}$ & TOMA & & $108-110$ & \\
$\mathbf{9}$ & TOMA & L-Phe & $<0^{[\mathrm{a}]}$ & L-phenylalanine \\
$\mathbf{1 0}$ & TOMP & $\mathrm{HOCOO}$ & $\approx 25^{[\mathrm{c}]}$ & $\mathrm{H}_{2} \mathrm{O}$ \\
$\mathbf{1 1}$ & TOMA & & $\approx 25^{[\mathrm{c}]}$ & \\
$\mathbf{1 2}$ & TOMP & $\mathrm{NTf}_{2}$ & $<0^{[\mathrm{a}]}$ & LiNTf \\
$\mathbf{1 3}$ & TOMA & & $<0^{[\mathrm{a}]}$ & \\
$\mathbf{1 4}$ & THMA & $\mathrm{CH}_{3} \mathrm{OCOO}$ & $<0^{[\mathrm{a}]}$ & - \\
\hline
\end{tabular}

[a] Remained liquid below freezing. [b] $\mathrm{nd}=$ not determined. [c] Deliquescent. 
perature of $60^{\circ} \mathrm{C}$ chosen for all the other products (see further on). Also not mentioned elsewhere is [THMA][ $\left.\mathrm{CH}_{3} \mathrm{OCOO}\right]$ (14), included to show that shorter-chain amines undergo the same reaction.

NMR spectroscopic characterisation: ${ }^{1} \mathrm{H}$ and ${ }^{13} \mathrm{C}\left\{{ }^{1} \mathrm{H}\right\} \mathrm{NMR}$ spectra of the ionic liquids were acquired neat, that is, without mixing them with other (e.g., deuterated) solvents. A calibrated glass capillary filled with $\left[\mathrm{D}_{6}\right] \mathrm{DMSO}$, coaxially inserted into the NMR spectroscopy tube, was used to lock the NMR spectroscopic signal. All the spectra are described in the Experimental Section and collected in the Supporting Information. Incredible natural-abundance double-quantum transfer experiment (INADEQUATE) and heteronuclear correlation experiments were used to assign each carbon atom along the aliphatic chains.

[TOMP][CH$\left.{ }_{3} \mathrm{OCOO}\right]$ (1) and [TOMP][HOCOO] (10)-catalysed Michael reactions: Both the $\left[\mathrm{CH}_{3} \mathrm{OCOO}\right]$ and [HOCOO] anions were expected to impart medium to good basicity to $\mathbf{1}$ and $\mathbf{1 0}$. This prompted us to investigate these ionic liquids for the generation and use of carbonucleophiles. The Michael reaction of nitroethane with cyclohexenone was chosen as a probe of their efficiency [Eq. (4)]. ${ }^{[27]}$

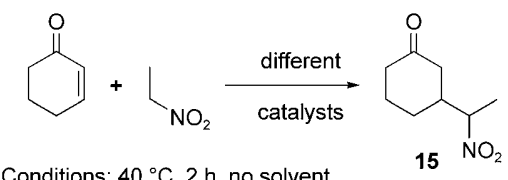

Conditions: $40^{\circ} \mathrm{C}, 2 \mathrm{~h}$, no solvent

It was immediately apparent that compounds $\mathbf{1}$ and $\mathbf{1 0}$ were unexpectedly active as strong bases, so much so that they needed not be used as functional solvents (i.e., in large quantities), but could be employed in truly catalytic amounts (0.004 molar equivalents with respect to cyclohexenone). A series of experiments was therefore carried out with catalytic amounts of $\mathbf{1}$ and $\mathbf{1 0}$ on the model reaction [Eq. (4)], and these were compared to results obtained using conventional basic catalysts able to generate carbonucleophiles, such as sterically hindered tertiary organic amines (1,8-diazabicyclo[5.4.0] undec-7-ene (DBU), 4-dimethylaminopyridine (DMAP) and 1,4-diazobicyclo[2.2.2] octane $(\mathrm{DABCO}))$, phosphazene base $\mathrm{P}_{1}-\mathrm{B} \mathrm{Bu}$, sodium bicarbonate and sodium hydroxide. A screening in search of the optimal molar ratio between catalyst $\mathbf{1 0}$ and cyclohexenone indicated that by using $\mathbf{1 0}$ as catalyst in the sequence $11,7,4$ and $2 \%$, the model Michael reaction was complete (100\% conversion) too rapidly (just a few minutes) at $40{ }^{\circ} \mathrm{C}$. Only at a $0.4 \% \mathbf{1 0} /$ cyclohexenone molar ratio did the reaction proceed sufficiently slowly to allow GC monitoring. All reactions were run thereafter without solvent, at $40^{\circ} \mathrm{C}$, for $2 \mathrm{~h}$, and using the fixed $0.4 \%$ catalyst/cyclohexenone ratio (Table 2 ). The reaction products obtained using $\mathbf{1 0}$ as catalyst could be isolated in high yields from the reaction mixture (see further on).
Table 2. Michael reaction of nitroethane with cyclohexenone using different bases. ${ }^{[\mathrm{a}]}$

\begin{tabular}{llclc}
\hline & Catalyst & $\mathrm{p} K_{\mathrm{a}}$ & Conv. [\%] $]^{[\mathrm{b}]}$ & Selectivity $^{[\mathrm{c}]}$ \\
\hline 1 & $\mathbf{1}$ & - & 87 & 100 \\
2 & $\mathbf{1 0}$ & - & 86 & 100 \\
3 & $\mathrm{P}_{1}-t \mathrm{Bu}^{[\mathrm{d}]}$ & $27^{[\mathrm{e}, \mathrm{f}]}$ & 82 & 100 \\
4 & $\mathrm{DBU}$ & $24^{[\mathrm{e}, \mathrm{g}]}$ & 77 & 92 \\
5 & $\mathrm{DMAP}$ & $18^{\mathrm{e}, \mathrm{g}]}$ & 0 & - \\
6 & $\mathrm{NaOH}$ & $15.7^{[\mathrm{h}]}$ & 7 & 100 \\
7 & $\mathrm{DABCO}$ & $8.5^{[\mathrm{e}, \mathrm{i}]}$ & 0 & - \\
8 & $\mathrm{NaHCO}_{3}$ & $6.4^{[\mathrm{h}]}$ & 0 & - \\
\hline
\end{tabular}

[a] Conditions: $40{ }^{\circ} \mathrm{C}, 2 \mathrm{~h}$, no solvent, catalyst/cyclohexenone molar ratio $=0.004$. $[\mathrm{b}]$ Conversion values were determined by GC. [c] Selectivity towards 15. [d] Phosphazene base. [e] In acetonitrile. [f] Ref. [28]. [g] Ref. [29]. [h] In aqueous solution. [i] Ref. [30].

Compounds $\mathbf{1}$ and $\mathbf{1 0}$ (entries 1 and 2, Table 2) proved more efficient than any of the other organic bases for the coupling of cyclohexenone and nitroethane. The comparison of the relative activity of $\mathbf{1}$ and $\mathbf{1 0}$ for the model Michael reaction indicated that with $\mathbf{1}$ it was slower than with the corresponding hydrogen carbonate 2 . Figure 1 shows the conversion versus time profiles for the Michael reactions cata-
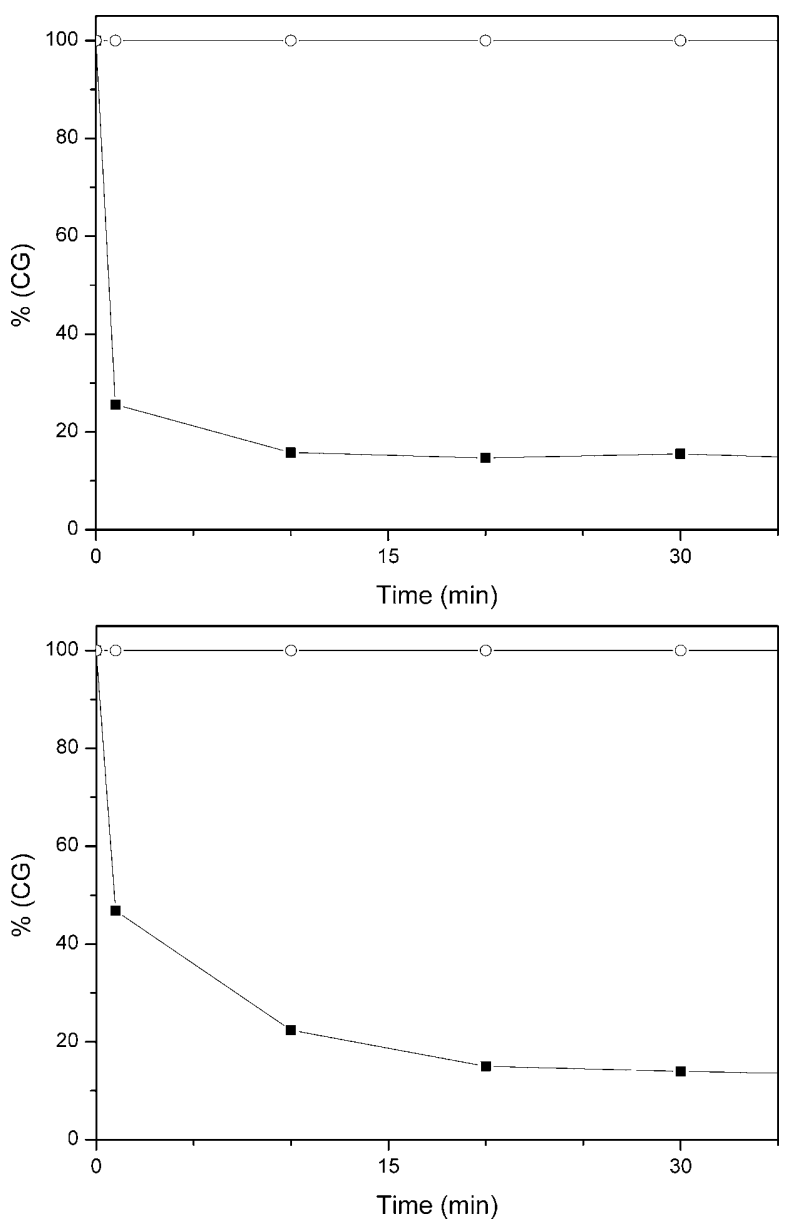

Figure 1. Time plots of the Michael reaction catalysed by [TOMP][HOCOO] (10; top) and [TOMP][ $\left.\mathrm{CH}_{3} \mathrm{OCOO}\right](\mathbf{1} ;$ bottom $) . \mathbf{m}=$ cyclohexenone; $O=$ selectivity. 
lysed by $\mathbf{1 0}$ and $\mathbf{1}$ used in $0.4 \mathrm{~mol} \%$ with respect to the substrates.

The same general trend was observed for the Michael reaction of cyclohexenone and nitroethane using [TOMA][HOCOO] (11) and [TOMA][ $\left.\mathrm{CH}_{3} \mathrm{OCOO}\right]$ (2). Hydrogen carbonate was faster than methyl carbonate, and both reached $80 \%$ conversion with $100 \%$ selectivity after $30 \mathrm{~min}$, although both reactions were slower than with the TOMP equivalent. $^{[31]}$

The Michael coupling reaction catalysed with $\mathbf{1 0}$ was also tested with a series of different donors. In all cases, the reactions were run in the absence of solvent, at $T=4-40^{\circ} \mathrm{C}$, with a Michael donor/acceptor ratio of 1.2 , and with a ratio of $\mathbf{1 0} / \mathrm{Mi}$ chael acceptor that was in the range of $2.0-0.4 \mathrm{~mol} \%$, therefore with $\mathbf{1 0}$ as a genuine catalyst. The results are collected in Table 3. The yields reported are isolated yields of purified (flash column chromatography), characterised products. It was found that the investigated reaction was not limited to nitroalkanes, but could be extended to $\beta$-dicarbonyl compounds as well. A different Michael acceptor, EVK, was also tested. It was more reactive than cyclohexenone in the Michael reactions using catalyst 10. Even at room temperature, it yielded instantaneously a mixture of mono and double Michael addition products. These reactions (Table 3, entries 5-8) were therefore carried out at $4{ }^{\circ} \mathrm{C}$ to control mono-addition selectivity.

\section{Discussion}

Quaternarisation with DMC: The direct syntheses of $\mathbf{1}$ and 2 from DMC yielded the onium methyl carbonate ionic liquids, thereby indicating that the reaction between the aliphatic nucleophilic amine or phosphine and DMC occurred probably through a direct nucleophilic attack of the amine (or phosphine) to the DMC methyl group by means of a $\mathrm{B}_{\mathrm{Al}} 2$ mechanism (Scheme 3). ${ }^{[37]}$
Table 3. Michael addition reactions catalysed by [TOMP][HOCOO] (10). ${ }^{[\mathrm{a}]}$

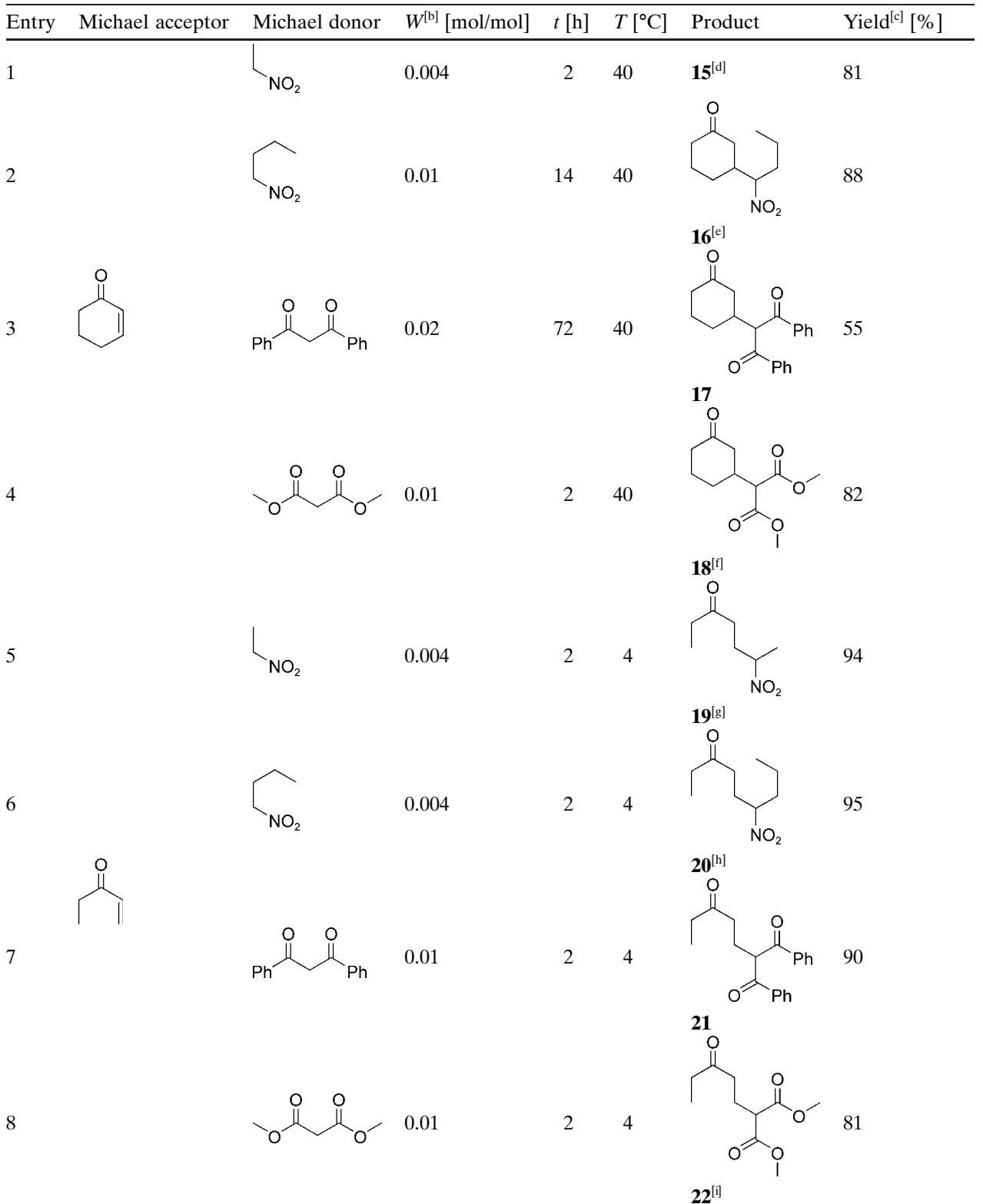

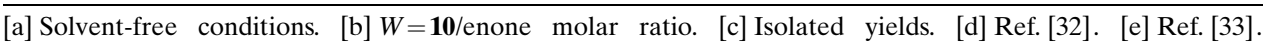
[f] Ref. [34]. [g] Ref. [27]. [h] Ref. [35]. [i] Ref. [36].

Earlier studies on different substrates (amines, phenols, etc.) had indicated that, at high temperature, the $\mathrm{B}_{\mathrm{Ac}} 2$ nucleophilic attack to the carbonyl was disfavoured, and that the $\mathrm{B}_{\mathrm{Al}} 2$ mechanism predominated, probably due to solvation effects dictated by the temperature. ${ }^{[38]}$ For this reason the $\mathrm{B}_{\mathrm{Ac}} 2$ mechanism to yield the carboxymethyltrialkylammoni-

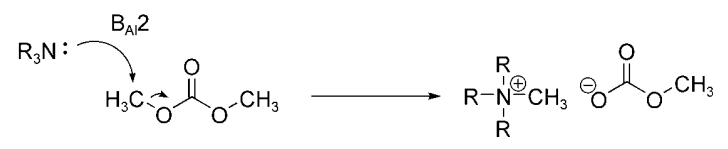

Scheme 3. Amine methylation: $\mathrm{B}_{\mathrm{Al}} 2$ mechanism. 
um salt, followed by elimination of $\mathrm{CO}_{2}$, was ruled out (Scheme 4).

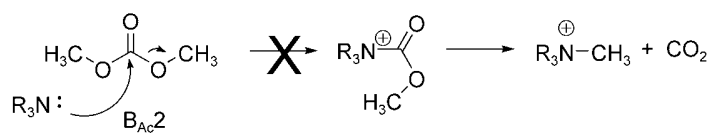

Scheme 4. Amine methylation: $\mathrm{B}_{\mathrm{Ac}} 2$ mechanism.

The reactions in Equations (1) and (2) afforded a quantitative yield, were $100 \%$ atom economic ${ }^{[39]}$ avoided the use of toxic and dangerous methyl halides and of DMS (Scheme 1), were totally halogen free and did not require workup with additional solvents to isolate and purify the products. From an environmental standpoint they were therefore green reactions, albeit somewhat energy intensive. ${ }^{[40]}$

Here it should be pointed out that the general environmental issue associated with the preparation of most ionic liquids begins upstream with the starting nitrogen and phosphorous compounds that are often toxic. For example, tertiary phosphines are prepared from toxic and dangerous $\mathrm{PH}_{3}$ and $\alpha$-olefins. ${ }^{[11]}$ It should also be noted that the methylation of amines and phosphines with DMC has a few recent, scarcely described, precedents in the literature: the methylation of trimethylamine ${ }^{[17]}$ and the preparation of CBILS. ${ }^{[16]}$ Commercial CBILS are sold as water-methanol solutions for a reason that is not clear to us; it may be due to the degradation of the methyl carbonate anion $\left[\mathrm{CH}_{3} \mathrm{OCOO}\right]$ under their reaction conditions. Nonetheless, in our case, the ionic liquids were perfectly stable as such, and it was certainly preferable to isolate them in their pure liquid form. The synthesis of ammonium salts with DMC using 1-ethyl-3-methylimidazolium bromide as a catalyst/medium was also reported recently. ${ }^{[42]}$ Here an imidazolium ionic liquid was used as promoter for the methylation with DMC, but the drawback was the obtainment of a mixture of ionic liquids that needed to be separated. This had to be done by additional washing with acetone. ${ }^{[43]}$

Anion metathesis: Although the reaction of the methyl carbonate ionic liquids $\mathbf{1}$ and $\mathbf{2}$ with Brønsted acids (Scheme 2) proceeded as expected to yield the anion $\left(\mathrm{A}^{-}\right)$-exchanged salts 3-9 of Table 1, treatment of $\mathbf{1}$ and $\mathbf{2}$ with water instead afforded the onium hydrogen carbonate ionic liquids $\mathbf{1 0}$ and 11 [Eq. (3)]. This reaction could take place either by direct hydrolysis of the methyl carbonate anion with water acting as a nucleophile (Scheme 5, top reaction), or by an acidbase reaction with water acting as an acid in analogy to Scheme 2, followed by methyl hydrogen carbonate decomposition ${ }^{[26]}$ and $\mathrm{CO}_{2}$ sequestration by hydroxide (Scheme 5, bottom).

Although this mechanism has not been investigated and available data do not permit a choice between path (a) and (b) of Scheme 5, the methyl carbonate anion is probably

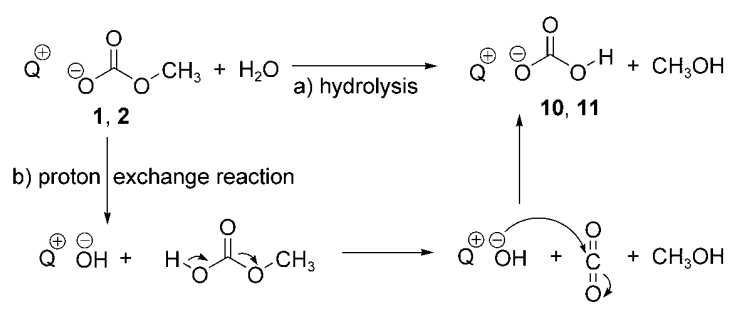

Scheme 5. Pathways for transformation of methyl carbonate into hydrogen carbonate anion.

more basic than it is electrophilic, thus favouring the bottom pathway.

NMR spectroscopic characterisation: ${ }^{1} \mathrm{H}$ and ${ }^{13} \mathrm{C}\left\{{ }^{1} \mathrm{H}\right\}$ NMR spectra were acquired neat for all the ionic liquids. If ionic liquids are intended as solvents, the most appropriate way to investigate their solvating ability for a given substrate is to avoid interferences by added solvents that could falsify the measurements. For example, the intermolecular solventsolute interactions between a chiral ionic liquid and a chiral or prochiral substrate can be studied, with a view toward understanding whether chiral interactions between solvent and solute take place. The ${ }^{1} \mathrm{H}$ NMR spectra were all quite similar to one another for the ammonium and phosphonium cations due to their structural identity. Instead, the ${ }^{13} \mathrm{C}\left\{{ }^{1} \mathrm{H}\right\}$ NMR spectra provided a wealth of information relative to the carbon backbone and on the purity of the compounds. In addition, quantitative integration of the ${ }^{13} \mathrm{C}$ resonance peaks allowed us to confirm cation-to-anion equimolarity. As an example, Figure 2 shows the ${ }^{13} \mathrm{C}\left\{{ }^{1} \mathrm{H}\right\}$ NMR spectrum of 1 with all the peak assignments. Carbon atoms $1,2,3$ and 9 show ${ }^{13} \mathrm{C}-{ }^{31} \mathrm{P}$ coupling; the carbonyl region is omitted.

Michael reactions catalysed by 1 and 10: [TOMP][CH$\left.{ }_{3} \mathrm{OCOO}\right](\mathbf{1})$ and [TOMP][HOCOO] (10; entries 7 and

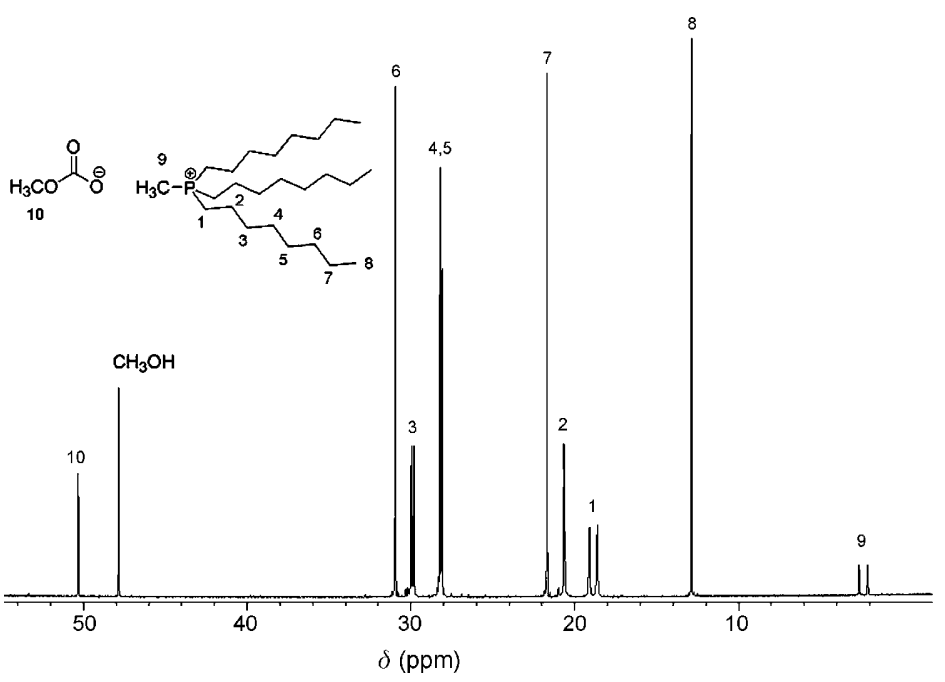

Figure $2 .{ }^{13} \mathrm{C}\left\{{ }^{1} \mathrm{H}\right\}$ NMR spectrum of neat [TOMP] $\left[\mathrm{CH}_{3} \mathrm{OCOO}\right](\mathbf{1})$. 
8 , Table 2) were expected to be somewhat basic, but in fact exceeded our expectations and could be used as catalysts rather than as solvent catalysts. Compounds $\mathbf{1}$ and $\mathbf{1 0}$ proved more efficient for the Michael addition of nitroethane to cyclohexenone than any of the other strong organic and inorganic bases tested, even when used in a mere $0.4 \mathrm{~mol} \%$ with respect to cyclohexenone. All reactions were run without solvent and at the same temperature $\left(40^{\circ} \mathrm{C}\right)$. Comparison of the $\mathrm{p} K_{\mathrm{a}}$ values (measured in $\mathrm{CH}_{3} \mathrm{CN}$ ) of sterically hindered tertiary organic amines (DBU, DMAP, DABCO) and phosphazene base $\mathrm{P}_{1}-t \mathrm{Bu}$, plus sodium bicarbonate and sodium hydroxide indicated that phosphazene $\left(\mathrm{p} K_{\mathrm{a}}=27\right)$ was the most basic together with DBU $\left(\mathrm{p} K_{\mathrm{a}}=24\right)$, followed by DMAP $\left(\mathrm{p} K_{\mathrm{a}}=18\right), \mathrm{NaOH}, \quad \mathrm{DABCO}$ and $\mathrm{NaHCO}_{3} \cdot{ }^{[4]}$ Table 2 shows that this basicity scale paralleled the catalytic activity trend observed for the Michael addition of nitroethane to cyclohexenone, with phosphazene yielding the highest conversion ( $82 \%$, entry 3 , Table 2$)$ after $2 \mathrm{~h}$. The ionic-liquid-based catalysts $\mathbf{1}$ and $\mathbf{1 0}$, on the other hand, reached $>85 \%$ conversion with $100 \%$ selectivity with respect to the substrates under the same conditions. These conversions were even higher than with phosphazene base $\mathrm{P}_{1}-t \mathrm{Bu}$ and DBU. DABCO and DMAP were completely inactive, as was sodium bicarbonate. The comparison of the catalytic activities of the trioctylmethylammonium bicarbonate $\mathbf{1 0}$ (entry 2, Table 2) and of $\mathrm{NaHCO}_{3}$ (entry 8, Table 2) was particularly striking, since $\mathbf{1 0}$ behaved as a base approximately two orders of magnitude stronger $\left(\mathrm{p} K_{\mathrm{a}}>25\right)$ than bicarbonate, thereby suggesting that the basic properties of the $[\mathrm{HOCOO}]$ anion were tremendously enhanced when coupled to the onium cation. The reason for the high basicity of the methyl carbonate and bicarbonate anions is still not clear and may depend on the lypophilic environment surrounding the anions and on solvation effects, as well as on the orientation of the negative charge with respect to the cation.

Comparison of the $\left[\mathrm{CH}_{3} \mathrm{OCOO}\right]$ and $[\mathrm{HOCOO}]$ anions indicated that $\mathbf{1}$ was slower than with the corresponding hydrogen carbonate (Figure 1), thereby implying that $\mathbf{1 0}$ was more basic than the methyl carbonate analogue, notwithstanding the $\mathrm{p} K_{\mathrm{a}}$ values of the acid-base reactions of their respective anions (5.6 and 3.6, respectively). ${ }^{[45]}$

\section{Conclusion}

In summary, we have developed and fully described a green synthetic procedure of a class of ionic liquids starting from amines, phosphines and DMC. The clear, colourless, halidefree ionic-liquid precursors $\mathbf{1}$ and $\mathbf{2}$ were isolated quantitatively and pure from the autoclave simply by removing the methanol and excess DMC under vacuum. They could then be simply anion-exchanged using acids or water (and no solvents) to yield a series of ionic liquids with different chemical and physical properties without any workup. Although the reaction conditions using DMC as methylating agent are more energy intensive $\left(T=140^{\circ} \mathrm{C}\right.$, sealed reactor) than those required for highly toxic dimethylsulfate (DMS) and methyl halides $\left(\mathrm{CH}_{3} \mathrm{X}\right)$, this apparent limitation is, however, largely compensated by the gain in greenness, ${ }^{[19]}$ including safety, handling and absence of waste products.

The bicarbonate-exchanged ionic liquids $\mathbf{1 0}$ and $\mathbf{1 1}$ showed very striking basicity, to the point of generating carbonucleophiles that could act as Michael donors, even when just in $0.4 \mathrm{~mol} \%$ with respect to the substrate. Comparison with known strong hindered bases indicated that the bicarbonate and methyl carbonate anions bearing the described onium cations enhanced their basicity by approximately two orders of magnitude.

This study is in progress, with a view toward extending the applicability of the described basic catalysts to other carbon-carbon bond-forming reactions, as well as in search of methodologies to improve upon the greenness of these materials, for example, by immobilising them on solid supports. Interactions between the ionic liquids and solutes is also under scrutiny to understand the nature of the basicity enhancement described here.

\section{Experimental Section}

General: Reagents were ACS grade and used as received. DMC, methanol, TFA, and $\mathrm{LiNTf}_{2}$, L-phenylalanine, 1-penten-3-one (EVK), dimethylmalonate, dibenzoylmethane, nitroethane and 1,4-diazabicyclo[2.2.2] octane were from Sigma-Aldrich. Tri- $n$-octylphosphine (TOP, $>98 \%$ ) was from Strem Chemicals (it should be used only if it appears as a clear liquid; cloudiness or a white solid are indicative of the phosphine oxide). Tri- $n$-octylamine (TOA), 2-cyclohexen-1-one, 1-nitrobutane and phosphazene base $\mathrm{P}_{1}-t \mathrm{Bu}$ (hexamethylphosphorimidic triamide) were from Fluka. ${ }^{1} \mathrm{H}$ and ${ }^{13} \mathrm{C}$ NMR spectra of all ionic liquids were collected neat at $60^{\circ} \mathrm{C}$ using a Varian Unity $400 \mathrm{MHz}$ spectrometer by locking the sample on $\left[\mathrm{D}_{6}\right]$ DMSO placed in a sealed capillary blocked in a coaxial position by means of a Teflon insert in the NMR spectroscopy tube. ${ }^{1} \mathrm{H}$ NMR spectra of solutions of Michael products in $\mathrm{CDCl}_{3}$ at $25^{\circ} \mathrm{C}$ were collected using a Varian Unity $400 \mathrm{MHz}$ spectrometer. Chemical shifts are reported downfield from TMS. INADEQUATE experiments were used to assign all the ${ }^{13} \mathrm{CNMR}$ spectroscopic signals in [TOMP]$\left[\mathrm{CH}_{3} \mathrm{OCOO}\right]$ and [TOMA] $\left[\mathrm{CH}_{3} \mathrm{OCOO}\right], \mathrm{HMBC}$ experiments were used to assign the peak of residual $\mathrm{MeOH}$ in the same samples, and $\mathrm{HMQC}$ to assign all ${ }^{1} \mathrm{H}$ peaks based on the correlation with the ${ }^{13} \mathrm{C}$ signals. The ${ }^{13} \mathrm{C}$ satellites were used, where possible, as internal standards to calculate the amount of impurities. ${ }^{[46]}$ Since, however, the ${ }^{1} \mathrm{H}$ NMR spectra were acquired in the neat phase, the vast majority of all the resonance bands were rather broad, thus making integration very tricky and subject to a large error. A conservative estimate indicates that the purity of the ionic liquids was greater than $95 \%$. GC-MS (EI, $70 \mathrm{eV}$ ) analyses were run using a HP5/MS capillary column $(30 \mathrm{~m})$. All reactions were repeated at least twice to ensure reproducibility.

Abbreviations: Dimethyl carbonate (DMC), tri- $n$-octylphosphine (TOP), tri- $n$-octylamine (TOA), dimethlysulfate (DMS), trifluoroacetic acid (TFA), generic onium cation $\left(\mathrm{Q}^{+}\right)$, generic anion $\left(\mathrm{A}^{-}\right)$, tri- $n$-octylmethylphosphonium (TOMP), tri- $n$-octylmethylammonium (TOMA), tri- $n$-hexylmethylammonium (THMA), bis(trifluoromethane)sulfonimide $\left(\mathrm{NTf}_{2}\right)$, L-phenylalaninate (L-Phe), 1,8-diazabicyclo[5.4.0]undec-7-ene (DBU), 4dimethylaminopyridine (DMAP), 1,4-diazabicyclo[2.2.2]octane (DABCO), ethyl vinyl ketone (EVK).

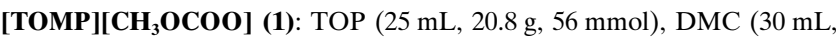
$32.1 \mathrm{~g}, 356 \mathrm{mmol})$ and methanol $(30 \mathrm{~mL})$ were combined (two phases) in a sealed $200 \mathrm{~mL}$ steel autoclave fitted with a pressure gauge and a thermocouple for temperature control. Three freeze-pump-thaw cycles were 
carried out to ensure complete degassing of the mixture and air removal. The empty volume was then filled with nitrogen. The autoclave was heated for $20 \mathrm{~h}$ at $140^{\circ} \mathrm{C}$ with magnetic stirring, after which time it was cooled and vented. Methanol and residual DMC were removed from the mixture by rotary evaporation, to give [TOMP] $\left[\mathrm{CH}_{3} \mathrm{OCOO}\right](27.5 \mathrm{~g}$, $100 \%)$ as a viscous clear colourless liquid (m.p. $<0^{\circ} \mathrm{C}$ ). A small amount $(<1$ equiv) of methanol may remain incorporated in the sample even after it has been subjected to prolonged high vacuum; it can be identified in the ${ }^{1} \mathrm{H}$ NMR spectrum by an HMBC experiment. It does not, however, affect future transformations. ${ }^{1} \mathrm{H} N M R$ (neat, $60^{\circ} \mathrm{C}, \quad 400 \mathrm{MHz}$, [D $\mathrm{D}_{6}$ DMSO): $\delta=3.15$ (s, 3H; $\mathrm{CH}_{3} \mathrm{OCOO}$ ), 2.33 (brt, $6 \mathrm{H} ; \mathrm{P}-\mathrm{CH}_{2}$ ), 1.88 $\left(\mathrm{d}, J(\mathrm{P}, \mathrm{H})=14 \mathrm{~Hz}, 3 \mathrm{H}\right.$; P-CH $\mathrm{CH}_{3}, 1.42(\mathrm{br}, 6 \mathrm{H}), 1.27$ (br, 6H), 1.11 (br, $24 \mathrm{H}$ ), $0.70 \mathrm{ppm} \quad($ brt,$\quad 9 \mathrm{H}) ;{ }^{13} \mathrm{C}\left\{{ }^{1} \mathrm{H}\right\} \mathrm{NMR}$ (neat, $60^{\circ} \mathrm{C}, \quad 100 \mathrm{MHz}$, [D $\mathrm{D}_{6}$ DMSO, $\mathrm{CH}_{2}$ assigned by $2 \mathrm{D}$ INADEQUATE $): \delta=155.8(1 \mathrm{C} ; C=\mathrm{O})$, $50.0\left(1 \mathrm{C} ; \mathrm{CH}_{3} \mathrm{O}\right), 30.9\left(3 \mathrm{C} ; \mathrm{C}_{6}\right), 29.9\left(\mathrm{~d}, J(\mathrm{P}, \mathrm{C})=15 \mathrm{~Hz}, 3 \mathrm{C} ; \mathrm{C}_{3}\right), 28.2$ $\left(3 \mathrm{C} ; \mathrm{C}_{5}\right), 28.0\left(3 \mathrm{C} ; \mathrm{C}_{4}\right), 21.6\left(3 \mathrm{C} ; \mathrm{C}_{7}\right), 20.7\left(\mathrm{~d}, J(\mathrm{P}, \mathrm{C})=4 \mathrm{~Hz}, 3 \mathrm{C} ; \mathrm{C}_{2}\right)$, $19.0\left(\mathrm{~d}, J(\mathrm{P}, \mathrm{C})=48 \mathrm{~Hz}, 3 \mathrm{C} ; \mathrm{C}_{1}\right), 12.8\left(3 \mathrm{C} ; \mathrm{C}_{8}\right), 2.6 \mathrm{ppm}(\mathrm{d}, J(\mathrm{P}, \mathrm{C})=$ $53 \mathrm{~Hz}, 3 \mathrm{C}$; P-CH ); IR (neat): $\tilde{v}_{\max }=2900,2856,1669 \mathrm{~cm}^{-1}$

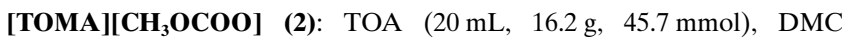
$(30 \mathrm{~mL}, 32.1 \mathrm{~g}, 356 \mathrm{mmol})$ and methanol $(20 \mathrm{~mL})$ were combined (two phases) in a sealed $200 \mathrm{~mL}$ steel autoclave fitted with a pressure gauge and a thermocouple for temperature control. Three vacuum-nitrogen cycles were carried out to ensure complete removal of air. The empty volume was then filled with nitrogen. The autoclave was heated for $20 \mathrm{~h}$ at $140^{\circ} \mathrm{C}$ with magnetic stirring, after which time it was cooled and vented. Methanol and residual DMC were removed from the mixture by rotary evaporation to give [TOMA] $\left[\mathrm{CH}_{3} \mathrm{OCOO}\right](20.0 \mathrm{~g}, 99 \%)$ as a viscous clear pale yellow liquid (m.p. $\left.<0{ }^{\circ} \mathrm{C}\right)$. A small amount $(<1$ equiv) of methanol may remain incorporated in the sample even after it has been subjected to prolonged high vacuum; it does not, however, affect future transformations. ${ }^{1} \mathrm{H} \mathrm{NMR}$ (neat, $60{ }^{\circ} \mathrm{C}, 400 \mathrm{MHz},\left[\mathrm{D}_{6}\right.$ ]DMSO): $\delta=3.36$ $\left(6 \mathrm{H} ; \mathrm{N}-\mathrm{CH}_{2}\right), 3.11\left(6 \mathrm{H} ; \mathrm{N}-\mathrm{CH}_{3}\right.$ and $\left.\mathrm{CH}_{3} \mathrm{O}\right), 1.54(\mathrm{br}, 6 \mathrm{H}), 1.08$ (br, $30 \mathrm{H}), 0.67 \mathrm{ppm}(9 \mathrm{H}) ;{ }^{13} \mathrm{C}\left\{{ }^{1} \mathrm{H}\right\} \mathrm{NMR}$ (neat, $60^{\circ} \mathrm{C}, 100 \mathrm{MHz},\left[\mathrm{D}_{6}\right] \mathrm{DMSO}$, $\mathrm{CH}_{2}$ assigned by 2D INADEQUATE): $\delta=155.5(1 \mathrm{C} ; \mathrm{C}=\mathrm{O}), 59.9(3 \mathrm{C}$; $\left.\mathrm{C}_{1}\right), 50.0\left(1 \mathrm{C} ; \mathrm{CH}_{3} \mathrm{O}\right), 46.8\left(1 \mathrm{C} ; \mathrm{N}-\mathrm{CH}_{3}\right), 30.9\left(3 \mathrm{C} ; \mathrm{C}_{6}\right), 28.2\left(6 \mathrm{C} ; \mathrm{C}_{5}-\mathrm{C}_{4}\right)$, $25.7\left(3 \mathrm{C} ; \mathrm{C}_{3}\right), 21.6\left(3 \mathrm{C} ; \mathrm{C}_{7}\right), 21.3\left(3 \mathrm{C} ; \mathrm{C}_{2}\right), 12.8 \mathrm{ppm}\left(3 \mathrm{C} ; \mathrm{C}_{8}\right)$; IR (neat): $\tilde{v}_{\max }=2900,2857,1669 \mathrm{~cm}^{-1}$.

[TOMP][CF $\mathbf{C O O}_{3}$ (3): TFA $(0.80 \mathrm{~g}, 7.0 \mathrm{mmol})$ was added dropwise over $5 \mathrm{~min}$ to [TOMP][ $\left.\mathrm{CH}_{3} \mathrm{OCOO}\right](1.52 \mathrm{~g}, 3.3 \mathrm{mmol})$, and the solution was stirred at $50^{\circ} \mathrm{C}$ for $2 \mathrm{~h}$. Excess TFA was removed under reduced pressure, and any residual TFA can be removed by dissolving the resulting liquid in $30 \mathrm{~mL}$ of $\mathrm{CH}_{2} \mathrm{Cl}_{2}$, washing with $2 \times 25 \mathrm{~mL}$ aliquots of $10 \%$ $\mathrm{NaHCO}_{3}$, followed by drying over $\mathrm{Na}_{2} \mathrm{SO}_{4}$, filtering, and removal of the solvent. [TOMP] $\left[\mathrm{CF}_{3} \mathrm{COO}\right](1.64 \mathrm{~g}, 97 \%)$ was obtained as a viscous clear liquid (m.p. $23-24^{\circ} \mathrm{C}$ ). ${ }^{1} \mathrm{H}$ NMR (neat, $60^{\circ} \mathrm{C}, 400 \mathrm{MHz},\left[\mathrm{D}_{6}\right] \mathrm{DMSO}$ ): $\delta=$ 2.25 (br, 6 H; P-CH $), 1.84\left(\mathrm{~d}, J(\mathrm{P}, \mathrm{H})=14 \mathrm{~Hz}, 3 \mathrm{H} ; \mathrm{P}-\mathrm{CH}_{3}\right), 1.39(\mathrm{br}, 6 \mathrm{H})$, 1.23 (br, 6H), 1.09 (br, 24H), 0.68 ppm (brt, 9H); ${ }^{13} \mathrm{C}\left\{{ }^{1} \mathrm{H}\right\}$ NMR (neat, $\left.60^{\circ} \mathrm{C}, 100 \mathrm{MHz},\left[\mathrm{D}_{6}\right] \mathrm{DMSO}\right): \delta=158.9(\mathrm{q}, J(\mathrm{~F}, \mathrm{C})=37 \mathrm{~Hz}, 1 \mathrm{C} ; C=\mathrm{O})$, $115.3\left(\mathrm{q}, J(\mathrm{~F}, \mathrm{C})=290 \mathrm{~Hz}, 1 \mathrm{C} ; C \mathrm{~F}_{3}\right), 30.6\left(3 \mathrm{C} ; \mathrm{C}_{6}\right), 29.4(\mathrm{~d}, J(\mathrm{P}, \mathrm{C})=$ $\left.14 \mathrm{~Hz}, 3 \mathrm{C} ; \mathrm{C}_{3}\right), 27.8\left(3 \mathrm{C} ; \mathrm{C}_{5}\right), 27.6\left(3 \mathrm{C} ; \mathrm{C}_{4}\right), 21.4\left(3 \mathrm{C} ; \mathrm{C}_{7}\right), 20.2(\mathrm{~d}$, $\left.J(\mathrm{P}, \mathrm{C})=5 \mathrm{~Hz}, 3 \mathrm{C} ; \mathrm{C}_{2}\right), 19.1\left(\mathrm{~d}, J(\mathrm{P}, \mathrm{C})=48 \mathrm{~Hz}, 3 \mathrm{C} ; \mathrm{C}_{1}\right), 12.6\left(\mathrm{C} 3, \mathrm{C}_{8}\right)$, $2.4 \mathrm{ppm}\left(\mathrm{d}, J(\mathrm{P}, \mathrm{C})=53 \mathrm{~Hz}, 3 \mathrm{C} ; \mathrm{P}-\mathrm{CH}_{3}\right)$; IR (neat): $\tilde{v}_{\max }=2900,1688$, 1467, 1199, 1164, $1122 \mathrm{~cm}^{-1}$

[TOMA][CF $\mathbf{C O O}$ (4): Compound 4 (3.2 g, $96 \%$ ) was synthesised using the same procedure as for [TOMP] $\left[\mathrm{CF}_{3} \mathrm{COO}\right] .{ }^{1} \mathrm{H} \mathrm{NMR}$ (neat, $60{ }^{\circ} \mathrm{C}$, $\left.400 \mathrm{MHz},\left[\mathrm{D}_{6}\right] \mathrm{DMSO}\right): \delta=3.21\left(\mathrm{br}, 6 \mathrm{H} ; \mathrm{N}-\mathrm{CH}_{2}\right), 3.00\left(3 \mathrm{H} ; \mathrm{N}-\mathrm{CH}_{3}\right), 1.51$ (br, 6H), 1.14 (br, 6H), 1.09 (br, 24H), $0.68 \mathrm{ppm}$ (brt, 9H); $\left.{ }^{13} \mathrm{C}{ }^{1} \mathrm{H}\right\}$ NMR (neat, $60^{\circ} \mathrm{C}, 100 \mathrm{MHz},\left[\mathrm{D}_{6}\right] \mathrm{DMSO}$ ): $\delta=158.2$ (q, $J(\mathrm{~F}, \mathrm{C})=$ $31 \mathrm{~Hz}, 1 \mathrm{C} ; C=\mathrm{O}), 116.9\left(\mathrm{q}, J(\mathrm{~F}, \mathrm{C})=299 \mathrm{~Hz}, 1 \mathrm{C} ; C_{3}\right), 60.2\left(3 \mathrm{C} ; \mathrm{C}_{1}\right), 47.0$ $\left(1 \mathrm{C} ; \mathrm{N}-\mathrm{CH}_{3}\right), 30.7\left(3 \mathrm{C} ; \mathrm{C}_{6}\right), 28.0\left(3 \mathrm{C} ; \mathrm{C}_{5}\right), 27.9\left(3 \mathrm{C} ; \mathrm{C}_{4}\right), 25.3\left(3 \mathrm{C} ; \mathrm{C}_{3}\right)$, $21.5\left(3 \mathrm{C} ; \mathrm{C}_{7}\right), 21.1\left(3 \mathrm{C} ; \mathrm{C}_{2}\right), 12.7 \mathrm{ppm}\left(3 \mathrm{C} ; \mathrm{C}_{8}\right)$; IR (neat): $\tilde{v}_{\max }=2900$, $2858,1688,1378,1199,1170,1125 \mathrm{~cm}^{-1}$.

[TOMP][NO $\mathbf{N O}_{3}$ (5): [TOMP][ $\left.\mathrm{CH}_{3} \mathrm{OCOO}\right](4.0 \mathrm{~g}, 8.13 \mathrm{mmol})$ was treated with aqueous concentrated $\mathrm{HNO}_{3}(0.60 \mathrm{~mL}, 9.2 \mathrm{mmol})$ at $50{ }^{\circ} \mathrm{C}$ for $2 \mathrm{~h}$. The mixture was cooled and extracted with dichloromethane. The organic extract was washed twice with saturated $\mathrm{NaHCO}_{3}(25 \mathrm{~mL})$ and the solvent was removed under vacuum to afford [TOMP][ $\left.\mathrm{NO}_{3}\right](3.5 \mathrm{~g},>95 \%)$ as a colourless liquid. ${ }^{1} \mathrm{H}$ NMR (neat, $60^{\circ} \mathrm{C}, 400 \mathrm{MHz},\left[\mathrm{D}_{6}\right] \mathrm{DMSO}$ ): $\delta=$
2.25 (br, $\left.6 \mathrm{H} ; \mathrm{P}-\mathrm{CH}_{2}\right), 1.79\left(\mathrm{~d}, J(\mathrm{P}, \mathrm{H})=13 \mathrm{~Hz}, 3 \mathrm{H} ; \mathrm{P}-\mathrm{CH}_{3}\right), 1.43$ (br, $\left.6 \mathrm{H}\right)$, 1.26 (br, 6H), 1.11 (br, 24H), 0.70 ppm (brt, 9H); ${ }^{13} \mathrm{C}\left\{{ }^{1} \mathrm{H}\right\}$ NMR (neat, $\left.60^{\circ} \mathrm{C}, 100 \mathrm{MHz},\left[\mathrm{D}_{6}\right] \mathrm{DMSO}\right): \delta=30.9\left(3 \mathrm{C} ; \mathrm{C}_{6}\right), 29.8(\mathrm{~d}, J(\mathrm{P}, \mathrm{C})=15 \mathrm{~Hz}$ $\left.3 \mathrm{C} ; \mathrm{C}_{3}\right), 28.1\left(3 \mathrm{C} ; \mathrm{C}_{5}\right), 28.0\left(3 \mathrm{C} ; \mathrm{C}_{4}\right), 21.7\left(3 \mathrm{C} ; \mathrm{C}_{7}\right), 20.5\left(3 \mathrm{C} ; \mathrm{C}_{2}\right), 19.0$ $\left(\mathrm{d}, J(\mathrm{P}, \mathrm{C})=49 \mathrm{~Hz}, 3 \mathrm{C} ; \mathrm{C}_{1}\right), 13.0\left(\mathrm{C} 3, \mathrm{C}_{8}\right), 2.5 \mathrm{ppm}(\mathrm{d}, J(\mathrm{P}, \mathrm{C})=51 \mathrm{~Hz}, 3 \mathrm{C}$; P- $\mathrm{CH}_{3}$ ); IR (neat): $\tilde{v}_{\max }=2930,2856,1467,1340 \mathrm{~cm}^{-1}$.

[TOMA][NO $\mathrm{NO}_{3}$ ] (6): Compound $6(2.8 \mathrm{~g},>95 \%)$ was synthesised using the same procedure as for $[\mathrm{TOMP}]\left[\mathrm{NO}_{3}\right] .{ }^{1} \mathrm{H} \mathrm{NMR}$ (neat, $60^{\circ} \mathrm{C}$, $\left.400 \mathrm{MHz},\left[\mathrm{D}_{6}\right] \mathrm{DMSO}\right): \delta=3.30\left(\mathrm{br}, 6 \mathrm{H} ; \mathrm{N}-\mathrm{CH}_{2}\right), 3.01\left(3 \mathrm{H} ; \mathrm{N}-\mathrm{CH}_{3}\right), 1.58$ (br, 6H), 1.17 (br, 6H), 1.11 (br, 24H), $0.71 \mathrm{ppm} ;{ }^{13} \mathrm{C}\left\{{ }^{1} \mathrm{H}\right\}$ NMR (neat, $\left.60{ }^{\circ} \mathrm{C}, 100 \mathrm{MHz},\left[\mathrm{D}_{6}\right] \mathrm{DMSO}\right): \delta=60.4\left(3 \mathrm{C} ; \mathrm{C}_{1}\right), 46.8\left(1 \mathrm{C} ; \mathrm{N}-\mathrm{CH}_{3}\right), 30.9$ $\left(3 \mathrm{C} ; \mathrm{C}_{6}\right), 28.2\left(6 \mathrm{C} ; \mathrm{C}_{5}-\mathrm{C}_{4}\right), 25.6\left(3 \mathrm{C} ; \mathrm{C}_{3}\right), 21.7\left(3 \mathrm{C} ; \mathrm{C}_{7}\right), 21.2\left(3 \mathrm{C} ; \mathrm{C}_{2}\right)$, $12.9 \mathrm{ppm}\left(3 \mathrm{C} ; \mathrm{C}_{8}\right)$; IR (neat): $\tilde{v}_{\max }=2930,2856,1467,1377 \mathrm{~cm}^{-1}$.

[TOMA][L-Phe] (9): L-Phenylalanine $(0.585 \mathrm{~g}, 2.9 \mathrm{mmol})$ was added to [TOMA] $\left[\mathrm{CH}_{3} \mathrm{OCOO}\right](1.28 \mathrm{~g}, 2.9 \mathrm{mmol})$. The mixture was stirred at $70^{\circ} \mathrm{C}$ under air for $1 \mathrm{~h}$, and then for an additional $3 \mathrm{~h}$ under vacuum to eliminate co-products (e.g., methanol, $\mathrm{CO}_{2}$ ); yield: $1.48 \mathrm{~g}, 96 \%$. ${ }^{1} \mathrm{H}$ NMR (neat, $\left.60^{\circ} \mathrm{C}, 400 \mathrm{MHz},\left[\mathrm{D}_{6}\right] \mathrm{DMSO}\right): \delta=6.96(2 \mathrm{H}), 6.84(2 \mathrm{H}), 6.73(2 \mathrm{H})$, 3.01 (br, 6H; N-CH $), 2.93\left(3 \mathrm{H} ; \mathrm{N}-\mathrm{CH}_{3}\right), 2.27(1 \mathrm{H}), 1.33$ (br, $\left.6 \mathrm{H}\right), 0.96$ (br, $30 \mathrm{H}$ ), $0.56 \mathrm{ppm} ;{ }^{13} \mathrm{C}\left\{{ }^{1} \mathrm{H}\right\} \mathrm{NMR}$ (neat, $60^{\circ} \mathrm{C}, 100 \mathrm{MHz},\left[\mathrm{D}_{6}\right] \mathrm{DMSO}$ ): $\delta=175.6,141.1,128.5,126.6,124.0,59.9\left(3 \mathrm{C} ; \mathrm{C}_{1}\right), 57.4,42.7,47.4(1 \mathrm{C} ; \mathrm{N}-$ $\left.\mathrm{CH}_{3}\right), 30.9\left(3 \mathrm{C} ; \mathrm{C}_{6}\right), 28.2\left(6 \mathrm{C} ; \mathrm{C}_{5}-\mathrm{C}_{4}\right), 25.6\left(3 \mathrm{C} ; \mathrm{C}_{3}\right), 21.6\left(3 \mathrm{C} ; \mathrm{C}_{7}\right), 21.3$ $\left(3 \mathrm{C} ; \mathrm{C}_{2}\right), 12.9 \mathrm{ppm}\left(3 \mathrm{C} ; \mathrm{C}_{8}\right)$; IR (neat): $\tilde{v}_{\max }=3411,2927,2857,1599$, $1380 \mathrm{~cm}^{-1}$.

[TOMP][HОCOO] (10): [TOMP][CH $\left.\mathrm{CH}_{3} \mathrm{OCOO}\right](3.0 \mathrm{~g}, 6.5 \mathrm{mmol})$ was stirred under air with water $(1 \mathrm{~mL})$ at $40^{\circ} \mathrm{C}$ for $2 \mathrm{~h}$. Excess water and methanol were removed under reduced pressure to yield [TOMP][HOCOO] $(2.9 \mathrm{~g}, 100 \%)$ as a viscous clear liquid that tends to solidify with time (m.p. $\approx 25^{\circ} \mathrm{C}$ ). ${ }^{1} \mathrm{H}$ NMR (neat, $60^{\circ} \mathrm{C}, 400 \mathrm{MHz},\left[\mathrm{D}_{6}\right] \mathrm{DMSO}$ ): $\delta=2.33$ (br, $6 \mathrm{H} ; \mathrm{P}-\mathrm{CH}_{2}$ ), $1.84\left(\mathrm{brd}, 3 \mathrm{H} ; \mathrm{P}-\mathrm{CH}_{3}\right), 1.33$ (br, $\left.6 \mathrm{H}\right), 1.23$ (br, $6 \mathrm{H}), 1.05$ (br, 24H), $0.64 \mathrm{ppm}($ brt, $9 \mathrm{H}) ;{ }^{13} \mathrm{C}\left\{{ }^{1} \mathrm{H}\right\} \mathrm{NMR}$ (neat, $60{ }^{\circ} \mathrm{C}$, $\left.100 \mathrm{MHz},\left[\mathrm{D}_{6}\right] \mathrm{DMSO}\right): \delta=158.9(1 \mathrm{C} ; \mathrm{C}=\mathrm{O}), 31.0\left(3 \mathrm{C} ; \mathrm{C}_{6}\right), 29.8(\mathrm{~d}$, $\left.J(\mathrm{P}, \mathrm{C})=15 \mathrm{~Hz}, 3 \mathrm{C} ; \mathrm{C}_{3}\right), 28.2\left(6 \mathrm{C} ; \mathrm{C}_{5}-\mathrm{C}_{4}\right), 21.6\left(3 \mathrm{C} ; \mathrm{C}_{7}\right), 20.9\left(3 \mathrm{C} ; \mathrm{C}_{2}\right)$, $19.1\left(\mathrm{~d}, J(\mathrm{P}, \mathrm{C})=49 \mathrm{~Hz}, 3 \mathrm{C} ; \mathrm{C}_{1}\right), 12.9\left(\mathrm{C} 3, \mathrm{C}_{8}\right), 2.9 \mathrm{ppm}(\mathrm{d}, J(\mathrm{P}, \mathrm{C})=52 \mathrm{~Hz}$, $3 \mathrm{C}$; $\mathrm{P}-\mathrm{CH}_{3}$ ); IR (neat): $\tilde{v}_{\max }=2900,2850,1650,1631 \mathrm{~cm}^{-1}$

[TOMА][HOCOO] (11): [TOMA][ $\left.\mathrm{CH}_{3} \mathrm{OCOO}\right](3.0 \mathrm{~g}, 6.8 \mathrm{mmol})$ was stirred under air with water $(1 \mathrm{~mL})$ at $40^{\circ} \mathrm{C}$ for $2 \mathrm{~h}$. Excess water and methanol were removed under reduced pressure to yield [TOMP][HOCOO] $(2.9 \mathrm{~g}, 100 \%)$ as a viscous clear liquid that tends to solidify with time (m.p. $\approx 25^{\circ} \mathrm{C}$ ). ${ }^{1} \mathrm{H}$ NMR (neat, $60^{\circ} \mathrm{C}, 400 \mathrm{MHz},\left[\mathrm{D}_{6}\right] \mathrm{DMSO}$ ): $\delta=5.14(\mathrm{~s}, \mathrm{OH}), 3.14$ (br, $\left.6 \mathrm{H} ; \mathrm{N}-\mathrm{CH}_{2}\right), 2.96$ (br, $\left.3 \mathrm{H} ; \mathrm{N}-\mathrm{CH}_{3}\right), 1.45$ (br, $6 \mathrm{H}), 1.12$ (br, 6H), 1.35 (br, 24H), $0.62 \mathrm{ppm}$ (brt, 9H); ${ }^{13} \mathrm{C}\left\{{ }^{1} \mathrm{H}\right\} \mathrm{NMR}$ (neat, $\left.60^{\circ} \mathrm{C}, 100 \mathrm{MHz},\left[\mathrm{D}_{6}\right] \mathrm{DMSO}\right): \delta=160.3(1 \mathrm{C} ; C=\mathrm{O}), 59.9\left(3 \mathrm{C} ; \mathrm{C}_{1}\right)$, $47.8\left(1 \mathrm{C} ; \mathrm{N}-\mathrm{CH}_{3}\right), 30.9\left(3 \mathrm{C} ; \mathrm{C}_{6}\right), 28.1\left(6 \mathrm{C} ; \mathrm{C}_{5}-\mathrm{C}_{4}\right), 25.3\left(3 \mathrm{C} ; \mathrm{C}_{3}\right), 21.6$ $\left(3 \mathrm{C} ; \mathrm{C}_{7}\right), 21.1\left(3 \mathrm{C} ; \mathrm{C}_{2}\right), 12.8 \mathrm{ppm}\left(3 \mathrm{C} ; \mathrm{C}_{8}\right)$; IR (neat): $\tilde{v}_{\max }=3406,2500$, $2856,1650,1631 \mathrm{~cm}^{-1}$.

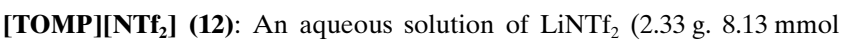
in $50 \mathrm{~mL}$ ) was added to [TOMP][ $\left.\mathrm{CH}_{3} \mathrm{OCOO}\right](4.0 \mathrm{~g}, 8.13 \mathrm{mmol})$ dissolved in water $(70 \mathrm{~mL})$. The mixture was stirred at $70^{\circ} \mathrm{C}$ for $2 \mathrm{~h}$. The resulting white precipitate was preferably extracted (but can be isolated by decanting as well) with $\mathrm{CH}_{2} \mathrm{Cl}_{2}$ to afford pure dry [TOMP] $\left[\mathrm{NTf}_{2}\right](3.05 \mathrm{~g}$, $60 \%$ ) as a clear liquid. ${ }^{1} \mathrm{H}$ NMR (neat, $\left.60{ }^{\circ} \mathrm{C}, 400 \mathrm{MHz},\left[\mathrm{D}_{6}\right] \mathrm{DMSO}\right): \delta=$ 1.96 (br, $6 \mathrm{H}$; P-CH $\left.\mathrm{CH}_{2}\right), 1.55\left(\mathrm{~d}, J(\mathrm{P}, \mathrm{H})=13 \mathrm{~Hz}, 3 \mathrm{H}\right.$; P-CH $\mathrm{CH}_{3}, 1.34(\mathrm{br}, 6 \mathrm{H})$, 1.24 (br, 6H), 1.09 (br, 24H), 0.68 ppm (brt, 9H); ${ }^{13} \mathrm{C}\left\{{ }^{1} \mathrm{H}\right\} \mathrm{NMR}$ (neat, $\left.60^{\circ} \mathrm{C}, 100 \mathrm{MHz},\left[\mathrm{D}_{6}\right] \mathrm{DMSO}\right): \delta=119.1\left(\mathrm{q}, J(\mathrm{~F}, \mathrm{C})=321 \mathrm{~Hz}, 2 \mathrm{C} ; C \mathrm{~F}_{3}\right)$, $30.6\left(3 \mathrm{C} ; \mathrm{C}_{6}\right), 29.3\left(\mathrm{~d}, J(\mathrm{P}, \mathrm{C})=15 \mathrm{~Hz}, 3 \mathrm{C} ; \mathrm{C}_{3}\right), 27.8\left(3 \mathrm{C} ; \mathrm{C}_{5}\right), 27.5(3 \mathrm{C}$; $\left.\mathrm{C}_{4}\right), 21.4\left(3 \mathrm{C} ; \mathrm{C}_{7}\right), 20.2\left(\mathrm{~d}, J(\mathrm{P}, \mathrm{C})=5 \mathrm{~Hz}, 3 \mathrm{C} ; \mathrm{C}_{2}\right), 19.0(\mathrm{~d}, J(\mathrm{P}, \mathrm{C})=48 \mathrm{~Hz}$, $\left.3 \mathrm{C} ; \mathrm{C}_{1}\right), 12.6\left(3 \mathrm{C} ; \mathrm{C}_{8}\right), 2.3 \mathrm{ppm}\left(\mathrm{d}, J(\mathrm{P}, \mathrm{C})=52 \mathrm{~Hz}, 3 \mathrm{C} ; \mathrm{P}-\mathrm{CH}_{3}\right)$; IR (neat): $\tilde{v}_{\max }=2930,2859,1468,1352 \mathrm{~cm}^{-1}$.

[TOMA][NTf ${ }_{2}$ ] (13): Compound $13(1.72 \mathrm{~g}, 65 \%)$ was synthesised using the same procedure as for $[\mathrm{TOMP}]\left[\mathrm{NTf}_{2}\right] .{ }^{1} \mathrm{HNMR}$ (neat, $60^{\circ} \mathrm{C}$, $\left.400 \mathrm{MHz},\left[\mathrm{D}_{6}\right] \mathrm{DMSO}\right): \delta=2.98\left(\mathrm{br}, 6 \mathrm{H} ; \mathrm{N}-\mathrm{CH}_{2}\right), 2.73\left(3 \mathrm{H} ; \mathrm{N}-\mathrm{CH}_{3}\right), 1.45$ (br, 6H), $1.12(\mathrm{br}, 6 \mathrm{H}), 1.07$ (br, $24 \mathrm{H}), 0.67 \mathrm{ppm}(\mathrm{t}, J=7.2 \mathrm{~Hz}, 9 \mathrm{H})$; ${ }^{13} \mathrm{C}\left\{{ }^{1} \mathrm{H}\right\}$ NMR (neat, $\left.60{ }^{\circ} \mathrm{C}, 100 \mathrm{MHz},\left[\mathrm{D}_{6}\right] \mathrm{DMSO}\right): \delta=119.1(\mathrm{q}, J(\mathrm{~F}, \mathrm{C})=$ $\left.322 \mathrm{~Hz}, 1 \mathrm{C} ; \mathrm{CF}_{3}\right), 60.8\left(3 \mathrm{C} ; \mathrm{C}_{1}\right), 46.9\left(1 \mathrm{C} ; \mathrm{N}-\mathrm{CH}_{3}\right), 30.5\left(3 \mathrm{C} ; \mathrm{C}_{6}\right), 27.8$ $\left(6 \mathrm{C} ; \mathrm{C}_{5}-\mathrm{C}_{4}\right), 25.0\left(3 \mathrm{C} ; \mathrm{C}_{3}\right), 21.4\left(3 \mathrm{C} ; \mathrm{C}_{7}\right), 21.0\left(3 \mathrm{C} ; \mathrm{C}_{2}\right), 12.6 \mathrm{ppm}(3 \mathrm{C}$; $C_{8}$ ); IR (neat): $\tilde{v}_{\max }=2929,2859,1469,1378,1353 \mathrm{~cm}^{-1}$. 


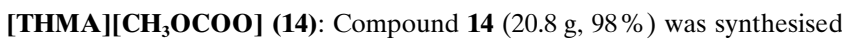
using the same procedure as for [TOMA] $\left[\mathrm{CH}_{3} \mathrm{OCOO}\right]$. Combined THA $(20 \mathrm{~mL}, 15.9 \mathrm{~g}, 59.0 \mathrm{mmol}), \mathrm{DMC}(30 \mathrm{~mL}, 32.1 \mathrm{~g}, 356 \mathrm{mmol})$ and methanol $(20 \mathrm{~mL}) .{ }^{1} \mathrm{H}$ NMR (neat, $\left.60^{\circ} \mathrm{C}, 400 \mathrm{MHz},\left[\mathrm{D}_{6}\right] \mathrm{DMSO}\right): \delta=3.32(\mathrm{br}$, $\left.6 \mathrm{H} ; \mathrm{N}-\mathrm{CH}_{2}\right), 3.10\left(3 \mathrm{H} ; \mathrm{N}-\mathrm{CH}_{3}\right), 3.06\left(3 \mathrm{H} ; \mathrm{CH}_{3} \mathrm{O}\right), 1.52(\mathrm{br}, 6 \mathrm{H}), 1.12$ (br, $24 \mathrm{H}$ ), $\left.0.67 \mathrm{ppm} ;{ }^{13} \mathrm{C}{ }^{1} \mathrm{H}\right\}$ NMR (neat, $60^{\circ} \mathrm{C}, 100 \mathrm{MHz},\left[\mathrm{D}_{6}\right] \mathrm{DMSO}$ ): $\delta=155.6(1 \mathrm{C} ; \mathrm{C}=\mathrm{O}), 60.1\left(3 \mathrm{C} ; \mathrm{C}_{1}\right), 50.0\left(1 \mathrm{C} ; \mathrm{CH}_{3} \mathrm{O}\right), 46.9\left(1 \mathrm{C} ; \mathrm{N}^{-C_{3}}\right)$, $30.4\left(3 \mathrm{C} ; \mathrm{C}_{6}\right), 25.3\left(3 \mathrm{C} ; \mathrm{C}_{3}\right), 21.5\left(3 \mathrm{C} ; \mathrm{C}_{7}\right), 21.3\left(3 \mathrm{C} ; \mathrm{C}_{2}\right), 12.8 \mathrm{ppm}(3 \mathrm{C}$; $\mathrm{C}_{8}$ ); IR (neat): $\tilde{v}_{\max }=3186,2956,2930,2860,1677,1634 \mathrm{~cm}^{-1}$

General procedure for the Michael reactions: A $7 \mathrm{~mL}$ glass reactor equipped with a side screw-capped neck for the withdrawal of samples and a condenser was charged with the reagents and the chosen catalyst (see Tables 2 and 3 and Figure 2). The reactor was heated to the desired temperature $\left(4-40^{\circ} \mathrm{C}\right)$ and the mixture was kept under magnetic stirring throughout the reaction. At intervals, samples of the reaction mixture were withdrawn and analysed by GC-MS. At the end of the reaction, the catalyst was removed by filtration on silica gel (weight ratio of silica gel/ catalyst $=80$; eluent, diethyl ether). The solution was concentrated under rotary evaporation and residual reactants were removed under high vacuum. The products were characterised by ${ }^{1} \mathrm{H}$ NMR spectroscopy by means of comparison with literature data.

Compound 15 (CAS registry no. 59969-93-6): A mixture of diastereomers (Table 3, entry 1); 2-cyclohexen-1-one ( $1.00 \mathrm{~mL}, 1.00 \mathrm{~g}, 10.4 \mathrm{mmol})$, nitroethane $(0.89 \mathrm{~mL}, 0.937 \mathrm{mg}, 12.5 \mathrm{mmol})$ and [TOMP][HOCOO] $(20 \mathrm{mg}$, $0.04 \mathrm{mmol}) .{ }^{1} \mathrm{H}$ NMR $\left(\mathrm{CDCl}_{3}, 400 \mathrm{MHz}\right): \delta=4.54-4.43(\mathrm{~m}, 1 \mathrm{H}), 2.48$ $2.06(\mathrm{~mm}, 6 \mathrm{H}), 1.98-1.83(\mathrm{~m}, 1 \mathrm{H}), 1.69-1.40 \mathrm{ppm}(\mathrm{mm}, 5 \mathrm{H})$

Compound 16: A mixture of diastereomers (Table 3, entry 2); 2-cyclohexen-1-one $(1.00 \mathrm{~mL}, 1.00 \mathrm{~g}, 10.4 \mathrm{mmol})$, nitrobutane $(1.32 \mathrm{~mL}, 1.287 \mathrm{~g}$, $12.5 \mathrm{mmol})$ and [TOMP][HOCOO] $(50 \mathrm{mg}, 0.1 \mathrm{mmol}) .{ }^{1} \mathrm{H} \mathrm{NMR}\left(\mathrm{CDCl}_{3}\right.$, $400 \mathrm{MHz}): \delta=4.44-4.31(\mathrm{~m}, 1 \mathrm{H}), 2.50-1.20(\mathrm{~mm}, 13 \mathrm{H}), 0.94-0.88 \mathrm{ppm}$ $(\mathrm{m}, 3 \mathrm{H})$.

Compound 17 (Table 3, entry 3): 2-Cyclohexen-1-one (0.4 mL, $0.4 \mathrm{~g}$, $4.16 \mathrm{mmol}$ ), dibenzoylmethane (448 $\mathrm{mg}, 2 \mathrm{mmol})$ and [TOMP][HOCOO] (50 mg, $0.1 \mathrm{mmol}$ ). The product was isolated by flash column chromatography using petroleum ether and ethyl acetate as eluents. ${ }^{1} \mathrm{H}$ NMR $\left(\mathrm{CDCl}_{3}, 400 \mathrm{MHz}\right): \delta=8.02-7.93(\mathrm{~m}, 4 \mathrm{H}), 7.60-7.53(\mathrm{~m}, 2 \mathrm{H}), 7.49-7.40$ $(\mathrm{m}, 4 \mathrm{H}), 5.23(\mathrm{~d}, J=8.5 \mathrm{~Hz}, 1 \mathrm{H}), 3.10-2.98(\mathrm{~m}, 1 \mathrm{H}), 2.47-2.36(\mathrm{~m}, 2 \mathrm{H})$, 2.32-2.22 (m, 2H), 2.09-2.00 (m, 1H), 1.98-1.90 (m, 1H), 1.76-1.63 (m, $1 \mathrm{H}), 1.62-1.50 \mathrm{ppm}(\mathrm{m}, 1 \mathrm{H})$.

Compound 18 (Table 3, entry 4): 2-Cycloexen-1-one (1.00 mL, $1.00 \mathrm{~g}$, $10.4 \mathrm{mmol})$, dimethylmalonate $(1.43 \mathrm{~mL}, \quad 1.650 \mathrm{~g}, \quad 12.5 \mathrm{mmol})$ and [TOMP][HOCOO] $(50 \mathrm{mg}, 0.1 \mathrm{mmol}) .{ }^{1} \mathrm{H}$ NMR $\left(\mathrm{CDCl}_{3}, 400 \mathrm{MHz}\right): \delta=$ $3.70(\mathrm{~s}, 3 \mathrm{H}), 3.69(\mathrm{~s}, 3 \mathrm{H}), 3.30(\mathrm{~d}, J=8.0 \mathrm{~Hz}, 1 \mathrm{H}), 2.54-2.42(\mathrm{~m}, 1 \mathrm{H})$, 2.41-2.30 (m, 2H), 2.27-2.15 (m, 2H), 2.07-1.98 (m, 1H), 1.93-1.85 (m, $1 \mathrm{H}), 1.70-156(\mathrm{~m}, 1 \mathrm{H}), 1.51-1.39 \mathrm{ppm}(\mathrm{m}, 1 \mathrm{H})$.

Compound 19 (Table 3, entry 5): 1-Penten-3-one $(1.03 \mathrm{~mL}, 874 \mathrm{mg}$, $10.4 \mathrm{mmol})$, nitroethane $(0.89 \mathrm{~mL}, 0.937 \mathrm{mg}, 12.5 \mathrm{mmol})$ and [TOMP][HOCOO] $(50 \mathrm{mg}, 0.1 \mathrm{mmol}) .{ }^{1} \mathrm{H}$ NMR $\left(\mathrm{CDCl}_{3}, 400 \mathrm{MHz}\right): \delta=4.65-4.54$ $(\mathrm{m}, 1 \mathrm{H}), 2.47(\mathrm{t}, J=7.0 \mathrm{~Hz}, 2 \mathrm{H}), 2.42(\mathrm{q}, J=7.3 \mathrm{~Hz}, 2 \mathrm{H}), 2.15-2.06(\mathrm{~m}$, $2 \mathrm{H}), 1.53(\mathrm{~d}, J=6.6 \mathrm{~Hz}, 3 \mathrm{H}), 1.04 \mathrm{ppm}(\mathrm{t}, J=7.3 \mathrm{~Hz}, 3 \mathrm{H})$.

Compound 20 (Table 3, entry 6): 1-Penten-3-one $(1.03 \mathrm{~mL}, 874 \mathrm{mg}$, $10.4 \mathrm{mmol})$, nitrobutane $(1.32 \mathrm{~mL}, 1.287 \mathrm{~g}, 12.5 \mathrm{mmol})$ and [TOMP][HOCOO] (50 mg, $0.1 \mathrm{mmol}) .{ }^{1} \mathrm{H}$ NMR $\left(\mathrm{CDCl}_{3}, 400 \mathrm{MHz}\right): \delta=4.53-4.44$ $(\mathrm{m}, 1 \mathrm{H}), 2.46-2.35(\mathrm{~m}, 4 \mathrm{H}), 2.14-2.03(\mathrm{~m}, 2 \mathrm{H}), 2.02-1.89(\mathrm{~m}, 2 \mathrm{H}), 1.72-$ $1.61(\mathrm{~m}, 1 \mathrm{H}), 1.45-1.35(\mathrm{~m}, 1 \mathrm{H}), 1.02(\mathrm{t}, J=7.3 \mathrm{~Hz}, 3 \mathrm{H}), 0.91 \mathrm{ppm}(\mathrm{t}, J=$ $7.3 \mathrm{~Hz}, 3 \mathrm{H})$

Compound 21 (Table 3, entry 7): 1-Penten-3-one (0.6 mL, $0.5 \mathrm{~g}$, $5.9 \mathrm{mmol})$, dibenzoylmethane $(448 \mathrm{mg}, 2 \mathrm{mmol})$ and [TOMP][HOCOO] $(25 \mathrm{mg}, 0.05 \mathrm{mmol})$. The product was isolated by flash column chromatography using petroleum ether and ethyl acetate as eluents. ${ }^{1} \mathrm{H}$ NMR $\left(\mathrm{CDCl}_{3}, 400 \mathrm{MHz}\right): \delta=8.06-8.02(\mathrm{~m}, 4 \mathrm{H}), 7.60-7.54(\mathrm{~m}, 2 \mathrm{H}), 7.50-7.43$ $(\mathrm{m}, 4 \mathrm{H}), 5.51(\mathrm{t}, J=6.8 \mathrm{~Hz}, 1 \mathrm{H}), 2.67(\mathrm{t}, J=6.4 \mathrm{~Hz}, 2 \mathrm{H}), 2.39(\mathrm{q}, J=$ $7.3 \mathrm{~Hz}, 2 \mathrm{H}), 2.33$ (q, $J=6.5 \mathrm{~Hz}, 2 \mathrm{H}), 1.04 \mathrm{ppm}(\mathrm{t}, J=7.3 \mathrm{~Hz}, 3 \mathrm{H})$.

Compound 22 (Table 3, entry 8): 1-Penten-3-one (1.03 mL, $874 \mathrm{mg}$, $10.4 \mathrm{mmol})$, dimethylmalonate $(1.43 \mathrm{~mL}, 1.650 \mathrm{~g}, 12.5 \mathrm{mmol})$ and [TOMP][HOCOO] $(50 \mathrm{mg}, 0.1 \mathrm{mmol}) .{ }^{1} \mathrm{H}$ NMR $\left(\mathrm{CDCl}_{3}, 400 \mathrm{MHz}\right): \delta=$ $3.71(\mathrm{~s}, 6 \mathrm{H}), 3.41(\mathrm{t}, J=7.3 \mathrm{~Hz}, 1 \mathrm{H}), 2.48(\mathrm{t}, J=7.2 \mathrm{~Hz}, 2 \mathrm{H}), 2.39(\mathrm{q}, J=$ $7.3 \mathrm{~Hz}, 2 \mathrm{H}), 2.14(\mathrm{q}, J=7.2 \mathrm{~Hz}, 2 \mathrm{H}), 1.02 \mathrm{ppm}(\mathrm{t}, J=7.3 \mathrm{~Hz}, 3 \mathrm{H})$.

\section{Acknowledgements}

The Ministero dell'Istruzione, Università e Ricerca and Regione Veneto are gratefully acknowledged for financial support.

[1] V. C. Pârvulescu, I. Hardacre, Chem. Rev. 2007, 107, 2615-2665.

[2] N. K. Plechkova, R. V. Seddon, Chem. Soc. Rev. 2008, 37, 123-150.

[3] R. Sheldon, Chem. Commun. 2001, 2399-2407.

[4] I. López-Martin, E. Burello, P. N. Davey, K. R. Seddon, G. Rothenberg, ChemPhysChem 2007, 8, 690-695.

[5] J. D. Holbrey, I. López-Martin, G. Rothenberg, K. R. Seddon, G. Silvero, X. Zheng, Green Chem. 2008, 10, 87-92.

[6] C. M. Starks, J. Am. Chem. Soc. 1971, 93, 195-199; C. M. Starks, C. L Liotta, M. Halpern, Phase-transfer Catalysis: Fundamentals, Applications, and Industrial Perspectives, Springer, New York, 1994

[7] C. J. Bradaric, A. Downard, C. Kennedy, A. J. Robertson, Y. Zhou, Green Chem. 2003, 5, 143-152.

[8] N. Karodia, S. Guise, C. Newlands, J.-A. Andersen, Chem. Commun. 1998, 2341-2342.

[9] K. Ma, K.-M. Lee, L. Minkova, R. G. Weiss, J. Org. Chem. 2009, 74, 2088-2098.

[10] T. Welton, Chem. Rev. 1999, 99, 2071-2083.

[11] P. Wasserscheid, R. van Hal, A. Bösmann, Green Chem. 2002, 4, $400-404$.

[12] "One-Step Process for the Preparation of Halide-Free Hydrophobic Salts": R. X. Ren, V. Koch, WO2002094883, 2002.

[13] C. C. Cassol, G. Ebeling, B. Ferrera, J. Dupont, Adv. Synth. Catal. 2006, 348, 243-248.

[14] J. D. Holbrey, W. M. Reichert, R. P. Swatloski, G. A. Broker, W. R. Pitner, K. R. Seddon, R. D. Rogers, Green Chem. 2002, 4, 407-413.

[15] "Method for Producing Ionic Liquids, Ionic Solids, or Mixtures Thereof": R. Kalb, W. Wesner, R. Hermann, M. Kotshan, M. Schlech, W. Staber, WO2005021484, 2005.

[16] http://www.sigmaaldrich.com/Area_of_Interest/Chemistry/Chemical_ Synthesis/Product_Highlights/CBILS.html.

17] O. Yagi, S. Shimizu, Chem. Lett. 1993, 2041-2044.

[18] M. Selva, P. Tundo, A. Perosa, J. Org. Chem. 2001, 66, 677-680; M. Selva, P. Tundo, A. Perosa, J. Org. Chem. 2002, 67, 9238-9247; M Selva, P. Tundo, A. Perosa, J. Org. Chem. 2003, 68, 7374-7378.

[19] M. Selva, A. Perosa, Green Chem. 2008, 10, 457-464.

[20] K. Sato, M. Aoki, M. Ogawa, T. Hashimoto, R. Noyori, J. Org. Chem. 1995, 60, 8310-8311.

[21] S. Paganelli, A. Perosa, M. Selva, Adv. Synth. Catal. 2007, 349, $1858-1862$.

[22] P. Tundo, A. Perosa, Chem. Soc. Rev. 2007, 36, 532-550.

[23] A. Perosa, P. Tundo, M. Selva, P. Canton, Chem. Commun. 2006, 4480-4482.

[24] M. Selva, P. Tundo, A. Perosa, F. Dall'Acqua, J. Org. Chem. 2005 , $70,2771-2777$.

[25] A. Loris, A. Perosa, M. Selva, P. Tundo, J. Org. Chem. 2004, 69, 3953-3956.

[26] G. Gattow, W. Behrendt Angew. Chem. 1972, 84, 549-549; Angew. Chem. Int. Ed. Engl. 1972, 11, 534-535; Angew. Chem. Int. Ed. Engl. 1972, 11, 534-535.

[27] We chose reaction (3) as a model because it can be easily monitored by GC and GC-MS; see also: R. Ballini, G. Bosica, Tetrahedron Lett. 1996, 37, 8027-8030.

[28] Y. Kondo in Superbases for Organic Synthesis (Ed.: T. Ishikawa), Wiley, New York, 2009, pp. 145-185.

[29] I. Kaljurand, T. Rodima, I. Leito, I. A. Koppel, R. Schwesinge, J. Org. Chem. 2000, 65, 6202-6208.

[30] J. Hine, Y.-J. Chen, J. Org. Chem. 1987, 52, 2091-2094.

[31] See Figure S23 in the Supporting Information. 
[32] D. E. Bergbreiter, J. J. Lalonde, J. Org. Chem. 1987, 52, 1601-1603.

[33] M. Yamaguchi, T. Shiraishi, Y. Igarashi, M. Hirama, Tetrahedron Lett. 1994, 35, 8233-8236.

[34] W. Yea, J. Xu, C.-T. Tan, C.-H. Tan, Tetrahedron Lett. 2005, 46, 6875-6878.

[35] R. Ballini, D. Fiorini, M. V. Gil, A. Palmieri, Tetrahedron 2004, 60, 2799-2804.

[36] L. Palombi, M. Feroci, M. Orsini, A. Inesi, Chem. Commun. 2004, 1846-1847.

[37] M. Selva, P. Tundo, Tetrahedron Lett. 2003, 44, 8139-8142.

[38] R. T. Fukuda, K. E. McIver, J. Am. Chem. Soc. 1979, 101, 24982499.

[39] Atom economy (AE) is defined as $\left[M_{\mathrm{r}}\left(\mathrm{g} \mathrm{mol}^{-1}\right)\right.$ of product $] /\left[\Sigma M_{\mathrm{r}}\right.$ $\left(\mathrm{g} \mathrm{mol}^{-1}\right)$ of all reagents] $\times 100$; see also: B. M. Trost, Science 1991, 254, 1471-1477.

[40] A rapid screening of the same reactions under microwave irradiation, rather than under thermal conditions, seemed to indicate that the ideal conditions for complete conversions and selectivity were elusive using MW and that the thermal reaction was more reliable.

[41] M. M. Rauhut, H. A. M. Currier, A. M. Semsel, V. P. Wystrach, J. Org. Chem. 1961, 26, 5138-5145.

[42] Z. Zheng, T. Wu, X. Zhou, Chem. Commun. 2006, 1864-1865.

[43] Z. Zheng, J. Wang, T. Wu, X. Zhou, Adv. Synth. Catal. 2007, 349, $1095-1101$.

[44] All $\mathrm{p} K_{\mathrm{a}}$ values except for $\mathrm{NaOH}$ and $\mathrm{Na}_{2} \mathrm{CO}_{3}$ were measured in $\mathrm{CH}_{3} \mathrm{CN}$.

[45] $\mathrm{p} K_{\mathrm{a}}=5.6$ refers to the equilibrium $\mathrm{CH}_{3} \mathrm{OCO}_{2} \mathrm{H} \rightleftharpoons \mathrm{CH}_{3} \mathrm{OCO}_{2}{ }^{-}+\mathrm{H}^{+}$; $\mathrm{p} K_{\mathrm{a}}=3.6$ is correct for the equilibrium $\mathrm{H}_{2} \mathrm{CO}_{3} \rightleftharpoons \mathrm{HCO}_{3}{ }^{-}+\mathrm{H}^{+}$in the absence of water. However, in aqueous solution the right-shifted equilibrium $\mathrm{H}_{2} \mathrm{CO}_{3} \rightleftharpoons \mathrm{CO}_{2}+\mathrm{H}_{2} \mathrm{O}$ predominates, thereby giving $\mathrm{p} K_{\mathrm{a}}=$ 6.4.

[46] C. C. Cassol, G. Ebeling, B. Ferrera, J. Dupont, Adv. Synth. Catal. 2006, 348, 243-248.

Received: July 8, 2009 Published online: October 6, 2009 